Review

\title{
Looking beyond Typical Treatments for Atypical Mycobacteria
}

\author{
Clara M. Bento ${ }^{1,2} \mathbb{D}$, Maria Salomé Gomes ${ }^{1,2,3, * \mathbb{C}}$ and Tânia Silva ${ }^{1,2} \mathbb{C}$ \\ 1 i3S-Instituto de Investigação e Inovação em Saúde, Universidade do Porto, 4200-135 Porto, Portugal; \\ clara.bento@i3s.up.pt (C.M.B.); tania.silva@ibmc.up.pt (T.S.) \\ 2 IBMC-Instituto de Biologia Molecular e Celular, Universidade do Porto, 4200-135 Porto, Portugal \\ 3 ICBAS-Instituto de Ciências Biomédicas Abel Salazar, Universidade do Porto, 4050-313 Porto, Portugal \\ * Correspondence: sgomes@ibmc.up.pt
}

Received: 16 December 2019; Accepted: 31 December 2019; Published: 3 January 2020

\begin{abstract}
The genus Mycobacterium comprises not only the deadliest of bacterial pathogens, Mycobacterium tuberculosis, but several other pathogenic species, including M. avium and M. abscessus. The incidence of infections caused by atypical or nontuberculous mycobacteria (NTM) has been steadily increasing, and is associated with a panoply of diseases, including pulmonary, soft-tissue, or disseminated infections. The treatment for NTM disease is particularly challenging, due to its long duration, to variability in bacterial susceptibility profiles, and to the lack of evidence-based guidelines. Treatment usually consists of a combination of at least three drugs taken from months to years, often leading to severe secondary effects and a high chance of relapse. Therefore, new treatment approaches are clearly needed. In this review, we identify the main limitations of current treatments and discuss different alternatives that have been put forward in recent years, with an emphasis on less conventional therapeutics, such as antimicrobial peptides, bacteriophages, iron chelators, or host-directed therapies. We also review new forms of the use of old drugs, including the repurposing of non-antibacterial molecules and the incorporation of antimicrobials into ionic liquids. We aim to stimulate advancements in testing these therapies in relevant models, in order to provide clinicians and patients with useful new tools with which to treat these devastating diseases.
\end{abstract}

Keywords: nontuberculous mycobacteria; antibiotics; ionic liquids; iron chelators; antimicrobial peptides; bacteriophages; host-directed therapies

\section{NTM Infections: Epidemiology and Clinical Presentations}

\subsection{Epidemiology}

Nontuberculous mycobacteria (NTM) are bacterial species that fall within the Mycobacterium genus, but which are outside the M. tuberculosis complex or the species M. leprae [1,2]. Around 190 NTM species are described, which are classified into two groups, i.e., the slowly growing (SGM), and the rapidly growing mycobacteria (RGM), according to the time required to form visible colonies in solid media (more or less than seven days, respectively). The most relevant NTM species for human disease are the members of the M. avium complex, M. kansasii and M. xenopi (all SGM), M. abscessus complex, M. chelonae, and M. fortuitum (the last three are RGM) [3-5]. All of these are environmental organisms, present mainly in soil and water. However, the incidence of human infections by NTM is increasing significantly worldwide. Although some mycobacterial species may cause other forms of disease, such as cutaneous infections, in this review, we will focus mainly on pulmonary disease. The exact numbers are difficult to find, as in most countries, the reporting of infections by NTM is not mandatory [5-7]. According to the available data, the incidence of disease varies considerably 
with NTM species, geographic distribution, sex, race/ethnicity, age, and risk factors (e.g., concomitant debilitating diseases). Women are at higher risk of infection, alongside people with Asian ancestry and from the Southern United States, such as Hawaii [8,9]. Species of the M. avium complex (MAC) are the most common causes of NTM infections and are mainly responsible for the observed increase in disease incidence $[3,5,6,10]$. Their resistance to antibiotics is growing; therefore, the treatment used today is a multidrug therapy comprising at least three antibiotics, with treatments taking from six months to years. However, a very long multidrug regimen like this results in several issues for patients, thereby decreasing the probability of success of the treatment. It is therefore urgent to find a new strategy to treat mycobacterial infections.

The fact that NTM with highly-hydrophobic cell walls, which facilitates aerosolization and surface adherence, are widely distributed in the environment, may explain their highly-infectious behavior. Moreover, NTM are able to survive in harsh environments, being exquisitely resistant to chlorine-based disinfectants, and their capacity to adhere to surfaces and form biofilms allows them to persist for long periods of time [10,11]. Biofilm formation and intercellular communication by quorum-sensing provide a high level of resistance to unfavorable environments and to the action of disinfectants and antibiotics. NTM, especially RGM, are also known to adhere to biomaterials, creating biofilms in medical devices, such as catheters, which may cause pathologies which are difficult to diagnose and treat [12].

\subsection{Relationship between Tuberculosis and NTM Infections}

Curiously, it has been reported that a local decline in tuberculosis (TB) incidence is coincidental with an increase in infections caused by NTM $[5,13,14]$. There is no single explanation for this phenomenon, but some can be hypothesized, e.g., cases of cross-immunity between M. tuberculosis $(\mathrm{Mtb})$ and NTM, in which each type of mycobacteria sensitizes the host to a second exposure of the other [15]. Also, better public health conditions can be, in this case, a double-edged sword. While improved ventilation and plumbing were essential to reducing TB incidence, centralized water supply systems, the disinfection of drinking water, and the habit of showering instead of tub-bathing are associated with NTM colonization, leading to the selection of these microorganisms due to their resistance to chlorination and higher exposure to mycobacteria through aerosolization $[10,11,16,17]$. Indeed, Mycobacterium was the most prevalent genus detected in showerheads throughout Europe and the United States, with a higher incidence in showerheads receiving municipal water (chlorine-treated water) [11,16]. Most surprisingly, Gebert et al. found that regions in the United States with high levels of NTM lung disease overlapped with high abundances of potential pathogenic NTM species detected in showerheads [16]. In health-care centers, the prevalence of NTM in plumbing systems is also very high, resulting in contamination and outbreaks associated with exposure to NTM-contaminated tap water of wounds, surgical instruments, prostheses, and dialysis-related equipment, among others [4,7]. Another important factor is the misdiagnosis of TB. In developing countries, where the incidence of TB is high, diagnoses usually do not distinguish between NTM and TB, only detecting a pulmonary mycobacteriosis. As a result, a significant number of NTM infections are classified as TB, and, as a consequence, these patients receive anti-TB therapy that is not effective against NTM. Thus, these patients are then classified as having either chronic or multidrug resistant (MDR) TB, with a high impact not only on their health status, but also on the associated health-costs [10].

It must always be borne in mind that higher clinical awareness and better diagnoses may explain the increased incidence rate of NTM infections in recent years. However, the increasing number of studies published worldwide every year reporting cases of NTM infection and the accumulated evidence they present indicate that these infections are indeed on the rise. Alterations in human lifestyle, including the massive use of plumbing water systems, the increased life expectancy, the growing use of immunosuppressive therapies, and increased human mobility and trade, all may be contributing to this trend [10]. 


\subsection{Clinical Presentations}

NTM human disease is thought to be acquired only from environmental sources, like exposure to tap water, soil, or the use of showers or cooling/heating devices, with no definitive evidence of human-to-human transmission [7,10,11,16-18]. However, there have been recent reports of possible transmission of M. abscessus between cystic fibrosis patients [3,19]. NTM disease can manifest essentially in four clinical syndromes: pulmonary disease (the most common form), skin and soft tissue infections, lymphatic disease, and disseminated disease [4]. Pulmonary disease usually occurs in individuals that are sensitized by other lung-associated diseases, like bronchiectasis, chronic obstructive pulmonary disease, cystic fibrosis, pneumoconiosis, or prior TB, among others, or with a compromised immune system due to conditions like rheumatoid arthritis, HIV-infection, cancer, or organ transplant [3]. Skin and soft tissue infection is associated with the contamination of wounds or prostheses and surgical procedures, and is more commonly associated with infection with RGM, like M. abscessus complex, $M$. chelonae, and M. fortuitum. The disseminated disease occurs in individuals with severely-compromised immune systems, especially in patients infected with HIV. NTM lymphatic disease is more commonly seen in immunocompetent children under 5 years old $[4,20]$.

\section{NTM Biology and Interaction with the Host Cell}

Mycobacteria are aerobic bacilli with a characteristic dense and complex cell wall. A thick layer of peptidoglycan gives structural strength to this wall. Additionally, mycolic acids, i.e., complex fatty acids of 60 to 90 carbons, are esterified with arabinogalactan, a sugar polymer, and confer high hydrophobicity and impermeability. The exterior part of the wall is composed of glycolipids and lipoglycans that interact with the mycolic acids and are covered by loose proteins, lipids, and glycans [21]. All these lipid layers make mycobacteria acid-fast, so they are not stained by the Gram method; instead, they require a harsh procedure like the Ziehl-Neelsen staining to be visualized [22].

Mycobacteria enter the body either by the respiratory (via aerosols) or gastrointestinal tract, or by wound and prosthesis contamination. Inside the host, these bacteria are found inside different cell types, but their main and most studied host cell is the macrophage. When mycobacteria infect macrophages, they localize in tight individual vacuoles, where they are able to grow exponentially [23]. It was observed that the vacuole also divides, accompanying the multiplication of the mycobacteria in order to maintain them in tight compartments. This strategy allows the mycobacteria to better control the fusion of their vacuoles with other vesicles that are present in the cell, like lysosomes. The arrest of the maturation of early mycobacterium-containing phagosomes is a well-known protective mechanism of these pathogens [23-25]. This mechanism is believed to prevent the exposure of the mycobacteria to the lysosome acidic environment, hydrolytic enzymes, and macrophage antigen-presenting organelles [26]. Additionally, it may facilitate the access of mycobacteria to nutrients, like iron, located in cell membrane-derived vesicles with which the early mycobacterium-containing phagosomes are able to interact $[23,27]$. Macrophages may also inhibit bacterial growth by mechanisms that involve oxidative damage, e.g., by nitric oxide, hydrogen peroxide, and superoxide. Interestingly, the NTM M. avium was shown to be more resistant than $\mathrm{Mtb}$ to both phagosome-lysosome fusion and oxidative damage [23]. This may be explained by a better adaptation of M. avium to harsh natural environments [27], in contrast to $\mathrm{Mtb}$, which can only survive inside the human host. On the other hand, this paradox indicates that macrophages must have other antimicrobial mechanisms that can control and eliminate NTM in immunocompetent individuals [28]. An alternative way of restricting the growth of intracellular pathogens is by depriving them of essential nutrients. Macrophage activation may prevent the interaction of the $M$. avium-containing phagosomes with endosomes that carry nutrients $[27,29]$. On the other hand, the protein SLC11A1 may contribute to mycobacterial growth restriction by pumping iron and other cations out of the pathogen-containing phagosome [28]. Macrophage autophagy and apoptosis have been increasingly identified as important mechanisms in the control of intracellular pathogens. However, it was shown that MAC are able to escape apoptotic bodies to the extracellular space, infecting and spreading to healthy cells and tissues [30]. 
The control of mycobacterial infection by the host relies on an immune response centered in $\mathrm{CD}^{+} \mathrm{T}$ cells that produce the macrophage-activating cytokine IFN- $\gamma$. The depletion of IFN- $\gamma$ or of upstream cytokines such as IL-12 and IL-18, which are necessary for the maturation of CD4 ${ }^{+}$T cells into IFN- $\gamma$-producing Th1 cells, exacerbates mycobacterial infection [27,31-33]. TNF is another important macrophage-activating cytokine. It increases the macrophage's antimycobacterial activity in vitro. Additionally, in vivo, TNF is involved in maintaining the structure and integrity of granulomas, i.e., the inflammatory lesions that are a hallmark of mycobacterial infections [27].

\section{Current Treatments Available for NTM Infections}

\subsection{Limitations and Challenges}

Some of the clinical features associated with pulmonary NTM infection are similar to those of $\mathrm{TB}$, caused by the closely-related pathogen, $\mathrm{Mtb}$ [34]. It is therefore comprehensible that the first treatments used for NTM infections were antituberculous drugs, which were successful in some cases, but demonstrated lower activity in this setting than against Mtb [35]. With the increasing incidence of NTM infections, mainly of MAC species, and the emergence of AIDS, a new strategy had to be adopted. The discovery of antibiotics that have a better effect against NTM infections than the antituberculous drugs which were previously used, such as the macrolides, revolutionized the treatment of NTM lung disease [35]. However, progress has been slow, with some renewed interest in recent years. The high number of NTM species and the similarity of the clinical features presented, concomitant with differences in the susceptibility to the available antibiotics, often hampers correct diagnoses and treatment. One of the important challenges when choosing an efficient treatment for NTM infection has been the lack of correlation between in vitro susceptibility patterns and the clinical response. This has contributed to delays in the implementation of appropriate guidelines, and has prompted treatment failure and the development of resistance [4]. For most NTM species, there are no evidence-based treatment recommendations, and clinicians are left to make decisions on a case-by-case basis.

In 2007, the American Thoracic Society (ATS) and the Infectious Diseases Society of America (IDSA) [4], and more recently the British Thoracic Society (BTS) [36], released a series of guidelines for the treatment of NTM pulmonary infections. The main consensus recommendation is the use of a macrolide-based multidrug regimen to treat pulmonary disease caused by MAC or M. abscessus complex (MABC) until the patient is sputum culture-negative for one year, which results in very long (months to years) treatments. Given the high toxicity and relatively low efficacy of available drugs, health professionals sometimes opt for no treatment in less severe cases, and patients are kept under clinical observation only. The prescription of multidrug therapy is fundamental to avoid macrolide resistance and to prevent unnecessary deaths in more severe cases, since surgical lung resection is often the only solution for patients who fail drug therapy due to antibiotic resistance [37]. Cases of re-infection with MAC after or during therapy are also of concern, affecting mainly patients with a severely immunocompromised system [35].

At the core of the failure of NTM infection treatments may be the lack of adherence to the established guidelines by health professionals [38-42]. Adjemian et al. performed a US survey where clinicians were asked to report treatment choices for NTM-infected patients treated in 2011 [39]. Surprisingly, of the 744 treatments prescribed against MAC, only 13\% met the ATS/IDSA guidelines, $56 \%$ did not include a macrolide, and $16 \%$ were on a macrolide monotherapy. In the case of the $174 \mathrm{MABC}$ infections, $64 \%$ of them were not treated with a macrolide [39].

\subsection{Base-Line Treatments for NTM}

The basis of all current treatments for NTM infections is macrolides. These antibiotics have the best correlation between in vitro susceptibility results and clinical (in vivo) response [35,37]. Clarithromycin or azithromycin are the usual options, with no significant differences in response between the two [43]. Clarithromycin has been more extensively studied, and it is often the preferred choice. However, 
it interferes with cytochrome P 3A enzymes, which may result in undesirable interactions with other drugs. To avoid this effect, azithromycin may be a better choice [44]. Macrolides inhibit protein synthesis in bacteria by binding to the $50 \mathrm{~S}$ ribosomal subunit and preventing the elongation of the nascent peptide chain [44,45]. Resistance to macrolides in several RGM species, such as M. abscessus, as well as in $\mathrm{Mtb}$, are related to the inducible macrolide resistance gene, $\mathrm{erm}$. The activation of this gene reduces the binding of macrolides to the ribosome by the methylation of an adenine in the $23 \mathrm{~S}$ rRNA $[37,43,44,46]$. A regimen of monotherapy with macrolides is, thus, very dangerous, as it will often lead to drug resistance and consequent treatment failure, associated with increased levels of mortality. The recommended treatment for MAC infection is a three-drug macrolide-based regimen with ethambutol and a rifamycin $[4,36,43]$. Since, as stated above, for many other species of NTM, there are no consistently effective drug combinations, therapy is often based on this same, three-drug macrolide-based regimen, eventually incorporating the results of the in vitro susceptibilities of the particular clinical isolates.

Ethambutol interferes with mycobacterial cell wall synthesis by the inhibition of arabinosyl transferases, which affects the synthesis of arabinogalactan and lipoarabinomannan. Its ability to alter the permeability of the cell wall, allowing the passage of other antimycobacterial drugs to occur, is its major advantage. Besides that, there are no known negative drug interactions with ethambutol. This antibiotic has good activity against SGM, including MAC, but high levels of resistance in RGM species exclude its use in this case $[37,44]$.

Rifamycins like rifampicin and rifabutin complete the bases of the treatment for NTM. They bind and inhibit DNA-dependent RNA polymerases, interrupting RNA synthesis early in the transcription process, displaying bactericidal activity [44]. They are a crucial part of the treatment against both NTM and $\mathrm{Mtb}$, as they are able to retain bactericidal activity against intramacrophagic and nonreplicating bacteria [47], as well as to sterilize the granulomas' necrotic center [48]. Co-infection with HIV may decrease the absorption of rifamycins, and notably, rifampicin is known to reduce the concentrations of several antiretroviral drugs. Rifamycins are involved in multiple interactions with other drugs, since they are strong inducers of CYP3A4, among other enzymes, and studies with patients infected with NTM showed low tolerance to rifabutin, although it was shown to have better in vitro and in vivo activity against MAC than rifampicin [37,43,44,49]. From the three types of drugs recommended to treat MAC infections, rifamycins contribute the most to suboptimal pharmacokinetics and pharmacodynamics parameters. In fact, poor antimycobacterial activities and several interactions with other agents, resulting in the reduction of the plasma concentration of these drugs, require the increase of dosages to levels that may become intolerable to patients $[43,46]$. In vitro susceptibilities to rifamycins and ethambutol do not correlate with treatment response, and thus, these results do not help clinicians to make treatment decisions. Rifamycins are a crucial part of the base treatment for MAC and M. kansasii; however, they are not recommended for the treatment of MABC, since these species are resistant to rifampicin [50]. Interestingly, in 2017 a screening of thousands of FDA-approved drugs showed that rifabutin is bactericidal against all MABC species, suggesting that this drug may be repurposed for the treatment of M. abscessus infections, and could also help to develop more potent ryfamicins [50,51].

\subsection{Second-Line Treatments for NTM}

Second-line drugs are of extreme importance in specific cases, like severely-disseminated or recalcitrant disease, and are essential in cases of macrolide-resistant MAC. Aminoglycosides, like amikacin or streptomycin, are protein synthesis inhibitors and are most often used in such cases [4]. It has been shown that in vitro minimal inhibitory concentration (MIC) for amikacin correlates well with clinical response, helping to predict treatment success [52]. Amikacin liposome inhalation suspension (ALIS) is a new promising alternative for these types of infections, and is, at present, in phase III trials for recalcitrant MAC lung disease after encouraging results in phase II $[43,53]$.

Fluoroquinolones, like moxifloxacin, are direct inhibitors of bacterial DNA synthesis, and have been included in the therapy of lung disease caused by macrolide-resistant MAC, although 
there is little evidence to support this. Moreover, their use as first-line drugs, as well as in a macrolide/fluoroquinolone regimen, is inadvisable due to the risk of drug resistance and cardiac toxicity $[36,37,43,44,46]$. Nonetheless, fluoroquinolones have significant activity against $M$. kansasii, and are of extreme importance in cases of rifamycin-resistant $M$. kansasii [54].

Clofazimine is a riminophenazine, acting as a prodrug that releases reactive oxygen species. It is part of the multidrug standard treatment used against $M$. leprae, and more recently, it has been repurposed for MDR-TB $[55,56]$. In the case of NTM, it has shown favorable activity against pulmonary disease $[57,58]$, and some data suggest that low tolerance to rifamycins can be overcome with clofazimine combined with a macrolide and ethambutol $[59,60]$. Clofazimine-containing regimens plus amikacin, isepamicin, or bedaquiline seem promising [54,61-64]. Moreover, due to its high penetration in skin and soft tissue, it has potential applications against NTM skin and soft tissue disease, like those caused by RGM [54].

Linezolid was the first member of the class of oxazolidinone antibiotics to be approved by the FDA to combat Gram-positive infections [65]. It has also been used as a second-line drug for the treatment of MDR-TB [55] and in patients who fail a macrolide-based regimen [4]. However, its poor tolerability and high toxicities in long-term treatment discourage its use [66]. Nevertheless, there are some data demonstrating that linezolid and other oxazolidinones [67-70] have potential in the treatment of NTM infections [68,71], especially those caused by RGM [72,73]. Several case reports describe the use of linezolid as being successful in the treatment of skin and soft tissue diseases caused by $M$. chelonae and M. abscessus [74-78].

Bedaquiline is a second-line antibiotic used in cases of MDR-TB $[79,80]$. It belongs to a new class of drugs approved in 2012 called diarylquinolines that act by binding and inhibiting the mycobacterial ATP synthase, resulting in ATP depletion and cell death [81]. Bedaquiline has been shown to have promising in vitro [82-90] and in vivo [91-93] activities against several species of NTM, including SGM and RGM. Moreover, preliminary results have shown that bedaquiline has potential clinical applications in patients with MAC or MABC lung disease [94,95]. The combination of bedaquiline with clofazimine is a promising addition to the NTM therapy [63]; however, there is emerging evidence that it has an antagonistic effect with clarithromycin and $\beta$-lactams [96], and that rifamycins reduce bedaquiline concentrations [97].

Delamanid belongs to a novel class of antibiotics, cyclic nitroimidazole, approved in 2014, to be used against MDR-TB. It acts as a prodrug, inhibiting the synthesis of mycolic acids [98]. Little data has been published on the activity of delamanid against NTM species, and what does exist has shown inconsistent results [98]. However, some studies have reported antimycobacterial activity, in particular against SGM species $[83,90,99]$.

\subsection{The Special Case of M. abscessus}

Diseases caused by species from the MABC are extremely difficult to cure, being, in some cases, comparable to MDR-TB. Macrolides are the only drugs with proven efficacy against MABC; however, as most clinical isolates have an active erm gene, it is of utmost importance to first determine which subspecies is the disease's causative agent. No evidence-based treatment exists, and due to its intrinsic resistance to many of the available drugs (e.g., all first-line anti-TB drugs), treatment is often aggressive, requiring a combination of a macrolide (when suitable) with at least two parenteral drugs, according to in vitro susceptibilities, like amikacin, linezolid, or $\beta$-lactams (imipenem or cefoxitin) [54]. However, it must be kept in mind that for most drugs, in vitro susceptibility does not correlate with clinical outcomes, leaving surgical resection as the last option for these patients. Recently, $\beta$-lactams (inhibitors of peptidoglycan synthesis), especially dual combinations of these drugs, have been repurposed for the treatment of MABC lung disease, with favorable in vitro $[100,101]$ and in vivo [102] results. Moreover, the combination with $\beta$-lactamase inhibitors (i.e., avibactam) improved the activity of several carbapenems and cephalosporins [100-108]. 


\subsection{New Antimycobacterial Compounds in Preclinical Studies}

Besides the discovery and development of new antibiotics, several reports have described the antimycobacterial activity of other types of molecules which are currently in preclinical studies. In Table 1, we summarize the most recent studies.

Table 1. Summary of recent publications showing new, promising antimicrobial agents against NTM species.

\begin{tabular}{|c|c|c|c|}
\hline Compound & Description & NTM & Ref. \\
\hline Nitric oxide & $\begin{array}{l}\text { Inhaled nitric oxide to treat MABC lung disease with } \\
\text { ongoing clinical trials. Shows synergistic effect with } \\
\text { antimycobacterial antibiotics, such as clofazimine. }\end{array}$ & M. abscessus & [109-111] \\
\hline PIPD1 & $\begin{array}{l}\text { Piperidinol-based molecule that targets mycolic acid } \\
\text { transport. }\end{array}$ & M. abscessus & [112] \\
\hline $\begin{array}{l}\text { Indolecarboxamide } \\
\text { analogs }\end{array}$ & $\begin{array}{c}\text { Structure-activity relationship studies of a series of } \\
\text { indolecarboxamide analogs that target mycolic acid } \\
\text { transport. }\end{array}$ & $\begin{array}{l}\text { M. abscessus; } \\
\text { M. chelonae; } \\
\text { M. massiliense; } \\
\text { M. bolletii; } \\
\text { MAC; } \\
\text { M. xenopi }\end{array}$ & {$[113,114]$} \\
\hline Benzimidazole SPR719 & $\begin{array}{l}\text { Active form of the prodrug SPR720, is an } \\
\text { aminobenzimidazole that inhibits the ATPase } \\
\text { activity of gyrase in Mtb. }\end{array}$ & $\begin{array}{c}\text { MAC; MABC; } \\
\text { M. chelonae; } \\
\text { M. immunogenum; } \\
\text { M. fortuitum; } \\
\text { M. mucogenicum; } \\
\text { M. kansasii; } \\
\text { M. marinum; } \\
\text { M. simiae }\end{array}$ & {$[115,116]$} \\
\hline TP-271 & $\begin{array}{l}\text { Novel fluorocycline antimicrobial related to } \\
\text { tetracycline; active in vitro against NTM isolates. }\end{array}$ & $\begin{array}{l}\text { M. abscessus; } \\
\text { M. fortuitum }\end{array}$ & [117] \\
\hline CyCs & $\begin{array}{l}\text { Cyclipostins and cyclophostin analogs with selective } \\
\text { in vitro and intramacrophagic activity against } \\
\text { mycobacteria; mechanism of action related to } \\
\text { enzyme-inhibition involved in lipid metabolism } \\
\text { and/or cell wall biosynthesis. }\end{array}$ & $\begin{array}{l}\text { M. abscessus; } \\
\text { M. marinum; } \\
\text { M. smegmatis }\end{array}$ & {$[118,119]$} \\
\hline $\begin{array}{l}\text { Salicylanilide esters, } \\
\text { carbamates and } \\
\text { benzoates }\end{array}$ & $\begin{array}{c}\text { De novo synthesized molecules with in vitro potency } \\
\text { against } M \text {. abscessus; ability to inhibit various } \\
\text { bacterial enzymes and to function as proton shuttles, } \\
\text { destroying the cellular proton gradient killing the } \\
\text { bacteria. }\end{array}$ & $\begin{array}{l}\text { M. abscessus; } \\
\text { M. avium; } \\
\text { M. kansasii }\end{array}$ & {$[120,121]$} \\
\hline Capuramycin analogs & $\begin{array}{c}\text { Nucleoside antibiotics that target peptidoglycan } \\
\text { synthesis, with in vitro activity against several } \\
\text { species of NTM. }\end{array}$ & $\begin{array}{c}\text { MAC; } \\
\text { M. paratuberculosis; } \\
\text { M. kansasii; } \\
\text { M. abscessus; } \\
\text { M. smegmatis; } \\
\text { M. ulcerans }\end{array}$ & {$[122,123]$} \\
\hline ACH-702 & $\begin{array}{l}\text { Isothiazoloquinolones, analogs related to quinolones, } \\
\text { which target bacterial replication; in vitro activity } \\
\text { against NTM. }\end{array}$ & $\begin{array}{l}\text { MAC; } \\
\text { M. fortuitum }\end{array}$ & [124] \\
\hline IAPs & $\begin{array}{l}\text { Imidazo [1,2-a]pyridine-3-carboxamides; potential } \\
\text { in vitro and in vivo activity against MAC. }\end{array}$ & MAC & [125] \\
\hline
\end{tabular}

\section{Alternative Approaches-Beyond Typical Treatments}

In light of the many difficulties and limitations identified above, it is evident that new antimycobacterial strategies must be developed to achieve better global control of NTM infections. New, alternative treatments should be able to allow shorter treatment durations, reduced daily pill burden and dose frequency, treatment of multidrug resistant strains, and the possibility of co-administration with other relevant drugs (e.g., anti-HIV drugs). In recent years, renewed efforts have been made towards the discovery of alternative approaches to tackle NTM infections. In the next sections, we will cover some of the most promising, new alternatives reported in the literature, which include the repurposing of conventional drugs and the use of ionic liquids, antimicrobial peptides, bacteriophages, iron chelators, and host-directed therapies (Figure 1). 


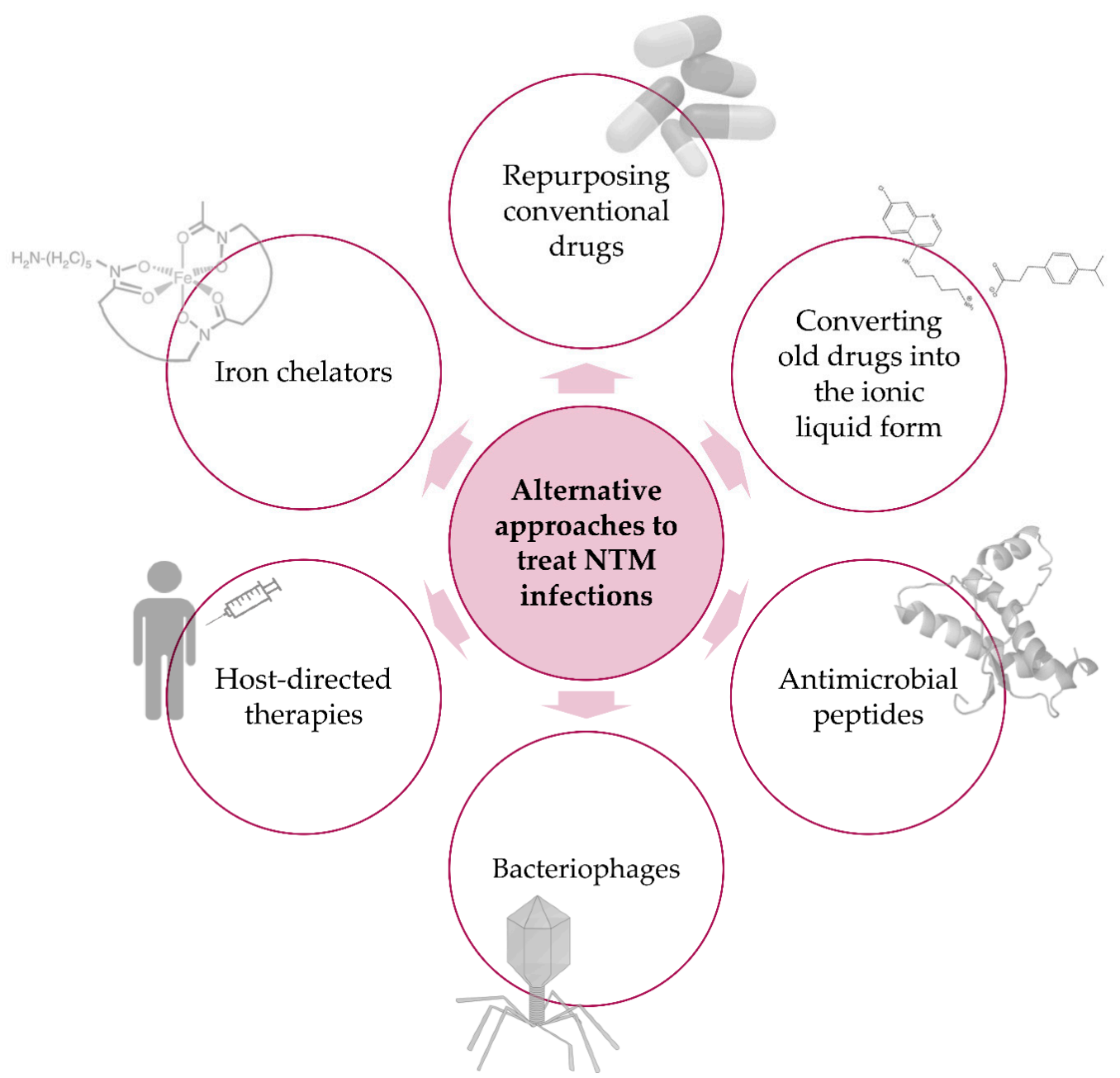

Figure 1. Alternative approaches to treat NTM infections. Schematic representation of new, promising alternatives to combat infectious diseases caused by NTM species.

\subsection{Repurposing Old Drugs}

The discovery of new drugs is extremely slow and costly. Repurposing drugs previously validated for other diseases accelerates the process while avoiding many of its difficulties. With this in mind, in recent decades, many researchers have turned to screening hundreds to thousands of previously developed or approved drugs for possible activity against different pathogens, including NTM $[50,126,127]$. These screenings can reveal a number of interesting hits that can be further explored in terms of in vitro and in vivo antimicrobial activity, mechanism of action, toxicity, resistance, synergism with other available drugs, and the possibility (or need) of fine-tuning to meet the new purpose. In Table 2, we list some of the promising compounds that could be repurposed for the treatment of NTM infections. 
Table 2. Summary of recent publications showing repurposed drugs with favorable activity against NTM infections.

\begin{tabular}{|c|c|c|c|}
\hline Compound & Description & NTM & Ref. \\
\hline Carvacrol & $\begin{array}{l}\text { Major constituent of many essential oils of the Labiatae } \\
\text { family; Generally recognized as safe (GRAS) and } \\
\text { approved for use in food; Antioxidant, } \\
\text { anti-inflammatory, antitumor, analgesic, antihepatotoxic, } \\
\text { and insecticidal activities; Activity in vitro against } \\
\text { planktonic and biofilm cells of several RGM. }\end{array}$ & $\begin{array}{l}\text { M. abscessus; } \\
\text { M. fortuitum; } \\
\text { M. chelonae; } \\
\text { M. mucogenicum; } \\
\text { M. smegmatis. } \\
\text { Biofilm inhibiting activity }\end{array}$ & {$[128,129]$} \\
\hline Omadacycline & $\begin{array}{c}\text { Tetracycline, used for skin infections and } \\
\text { community-acquired pneumonia caused by } \\
\text { Gram-positive bacteria; In vitro activity against } \\
\text { M. abscessus. }\end{array}$ & $\begin{array}{l}\text { M. abscessus; } \\
\text { M. chelonae; } \\
\text { M. fortuitum }\end{array}$ & [130-133] \\
\hline $\begin{array}{l}\text { Mefloquine and } \\
\text { enantiomers }\end{array}$ & $\begin{array}{l}\text { Derivative of 4-quinolinemethanol; An antimicrobial } \\
\text { drug used against chloroquine-resistant Plasmodium } \\
\text { falciparum; Active in vitro and in vivo against MAC; } \\
\text { Synergistic effect with antimycobacterial drugs in vivo. }\end{array}$ & MAC & [134-136] \\
\hline Thioridazine & $\begin{array}{l}\text { Phenothiazine derivative, an antipsychotic drug with } \\
\text { activity against Mtb, by inhibition of the electron } \\
\text { transport chain; In vitro activity in a hollow-fiber system } \\
\text { model for pulmonary MAC disease (HFS-MAC). }\end{array}$ & MAC & {$[137,138]$} \\
\hline Chloroquine & $\begin{array}{l}\text { Antimalarial with activity in vitro and in vivo against } M . \\
\text { avium. Also active in vitro against HIV-1. }\end{array}$ & MAC & [139] \\
\hline Primaquine & $\begin{array}{l}\text { Urea derivatives of this antimalarial showed high } \\
\text { activity in vitro against } M \text {. avium. }\end{array}$ & MAC & [140] \\
\hline
\end{tabular}

In this list, we find very different molecules, either of natural origin, such as carvacrol, or that have been originally developed for unrelated diseases, such as the antipsychotic, thioridazine. Additionally, several of these drugs were previously shown to have antiparasitic activity, including antimalarial agents. Chloroquine (CQ) was first synthesized during World War II, being identified as the most promising antimalarial drug due to its good efficacy, low toxicity, tolerable adverse effects, and affordability $[141,142]$. Besides malaria, it was demonstrated that CQ has anti-HIV-1 and antiM. avium activity in vitro [139], suggesting it can be viewed as a multiversed drug in the treatment of AIDS-related opportunistic infections. Experiments in our laboratory showed that CQ has a significant inhibitory effect in vitro against M. avium [139]. That inhibitory effect was also evident in vivo: BALB/c and C.D 2 mice infected with M. avium 2447 SmT treated with $30 \mathrm{mg} / \mathrm{kg}$ of CQ every other day showed a significant decrease of bacterial loads in the liver (unpublished results). Primaquine (PQ) is the most effective and least toxic 8-aminoquinoline to have been used as an antimalarial since the 1950s [143]. More recently, it was reported that primaquine at $5 \mu \mathrm{M}$ was able to inhibit the intracellular growth of Mtb [144], and some PQ-derivatives tested against Mtb, M. paratuberculosis, and MAC showed strong antimycobacterial activity [140].

\subsection{Ionic Liquids}

In the rescue of old and less utilized drugs, unfavorable pharmacological properties, such as low solubility, spontaneous crystallization, and the high dosage needed to achieve the desirable effects or toxicity to the host infected cells, are common problems. These difficulties can be overcome by the synthesis of noncrystalline forms of those drugs, i.e., ionic liquids (ILs), which are organic salts made by the combination of the active pharmaceutical ingredient in its cationic or anionic form and an inert counterion, or a counterion which is of additional biological interest. The cost of this synthesis can even be lowered by, for example, combining existing drugs of opposed polarities [145-147].

With remarkable physical and chemical properties, ILs were first used to improve the performance and safety of chemical procedures as green-solvents. Recent studies regarding the interaction between ILs and biomaterials have revealed their strong potential to improve sensors and drug delivery systems [147]. It has been demonstrated that ILs work well as antimicrobial agents, affecting Gram-positive and -negative bacteria, but also mycobacteria and fungi [147]. The right combination of cations and anions can provide innovative compounds that help combat resistance 
issues. The mechanism of action of ILs, as compared to conventional drugs, is not yet fully understood. However, structural characteristics such as the length of the cation side chain or the presence of polar functional groups can alter properties, such as lipophilicity and surface tension, that are known to influence the activity of the compounds [147]. As active pharmaceutical ingredients, ILs are emerging as a promising means by which to overcome issues related to polymorphism while improving solubility and bioavailability in a cost-effective way.

The combination of anionic ampicillin with organic cations resulted in ILs with activity against Gram-negative bacteria resistant to antibiotics [148]. ILs derived from a classical antimalarial drug, primaquine, an 8-aminoquinoline, were found to exhibit improved in vitro performance in comparison to primaquine, and better in vitro activities than their covalent analogs [145]. ILs derived from N-cinnamoylated CQ conjugates were reported to have similar activity against Pneumocystis jirovecii than their covalent equivalents; however, they were shown to be less cytotoxic to two different cell lines than their covalent equivalents [149]. Recently, our group tested ILs based on the cationic molecule of CQ and differently-substituted anionic cinnamoyl groups against M. avium. Although these ILs did not show a better inhibitory effect than their covalent equivalents, they were significantly more soluble and less toxic to macrophages harboring the bacteria [150]. These results confirm the ability of ILs to overcome the pharmacological issues associated with their drugs of origin.

ILs are very promising in terms of efficacy, affordability, and as a form of bypassing problems of resistance. Their properties allow conventional drugs to be combined, with different effects but with a joint purpose. For example, bacterial infection in an AIDS patient could be treated in the future with only one medicine, an IL comprising an antiretroviral ion and a counterion with antibacterial activity.

\subsection{Antimicrobial Peptides}

Antimicrobial peptides (AMPs) compromise a vast array of small peptidic compounds that exhibit antimicrobial activity against a wide variety of pathogens (viruses, bacteria, fungi, and protozoans). AMPs are widespread in nature, i.e., they are present in almost all living organisms as part of their innate immune mechanisms. These compounds are highly diverse in their length, sequence, structure, source, and activity; as a result of such diversity, there is no universal target or defined mechanism of action. Nonetheless, it is well known that they interact with pathogens' cytoplasmic membranes, disrupting them or not, which can lead to cellular death; they can also act intracellularly, interacting with fundamental molecules, such as DNA, RNA, or proteins [151]. Moreover, AMPs can also have immunomodulatory properties, and for that reason, they have been called "host defense peptides" [152,153]. This multitude of actions increases AMP efficacy, but above all, enables them to escape potential microbial resistance mechanisms. Of interest, AMPs do not distinguish between metabolically-active or inactive microbial cells, as opposed to conventional antibiotics [154], which increases their scope of action, especially against biofilms. Bearing all this in mind, AMPs are an attractive alternative approach in the fight against bacterial diseases. AMPs have been described to be active against mycobacteria, both through directly killing or immunomodulation (reviewed in $[153,155,156])$. Most notable is the role of the human peptide cathelicidin LL-37, which induces autophagy and phagosomal maturation in mycobacteria-infected macrophages via the activation of vitamin D signaling pathways [157]. Moreover, it was shown that the production of cathelicidins and several defensins (e.g., human neutrophil peptide (HNP) and beta-defensins) is upregulated during mycobacterial infections [155]. Additionally, in some cases, the effect of AMPs in vivo is achieved at lower concentrations than those necessary for in vitro antimicrobial activity, indicating that their mechanism of action is much more complex than just the direct membrane disruption [158,159]. The combination of AMPs with conventional antibiotics is also of interest, since it could lead to a reduction in dosage requirements of each agent, treatment duration, and the emergence of resistance [156,160]. This favorable combination could arise not only from the synergy of both antimicrobial activities, but because by acting on the pathogen membranes, AMPs can facilitate the entrance of other drugs. Moreover, due to their immunomodulatory properties, AMPs can be used as adjuvants, priming the 
immune system in several different manners, such as through the modulation of pro-inflammatory and anti-inflammatory cytokine production, the recruitment, activation, and differentiation of immune cells, the regulation of cell death pathways, and wound healing [152].

Several reports have described the capacity of AMP to kill or inhibit the growth of NTM, including M. avium, M. abscessus, M. chelonae, M. marinum, M. fortuitum, M. massiliense, and M. kansasii (Table 3). These peptides come from diverse sources, going from bacteriocins (produced by bacteria) [161-166] to mammalian peptides like cathelicidins, human neutrophil peptide ( $\alpha$-defensins), and lactoferricin [167-171], but also including invertebrates like clams and arthropods [172-176]. Nonetheless, as happens for other new treatments, most of these studies are mainly directed towards $\mathrm{Mtb}$, and the experimental use of NTM is often a way to overcome biosafety and experimental problems, or to address the peptides' activity spectrum. Nonetheless, the increasing number of original reports and reviews describing the antimycobacterial activity of different AMPs highlights the potential of these peptides to be used as new drugs in the fight against mycobacterial infections (Table 3).

Table 3. Summary of AMP activity against NTM.

\begin{tabular}{|c|c|c|c|c|}
\hline AMP & Origin & NTM Species & Activity & Ref. \\
\hline Ecumicin & Extracts from actinomycetes & $\begin{array}{l}\text { M. abscessus; } \\
\text { M. chelonae; } \\
\text { M. marinum; } \\
\text { M. kansasii; } \\
\text { M. avium }\end{array}$ & Axenic & [162] \\
\hline Lassomycin & Extracts from actinomycetes & M. avium & Axenic & [163] \\
\hline Nisin & Lactococcus lactis & M. paratuberculosis & Axenic & {$[166]$} \\
\hline Nisin A, S, T, and V & Lactococcus lactis & $\begin{array}{l}\text { M. kansasii; } \\
\text { M. avium }\end{array}$ & Axenic & [165] \\
\hline Lacticin 3147 & Lactococcus lactis & $\begin{array}{l}\text { M. kansasii; } \\
\text { M. avium }\end{array}$ & Axenic & [164] \\
\hline LL-37 & Human Cathelicidin & M. avium & Macrophages & [167] \\
\hline $\begin{array}{l}\text { LLKKK-18 (plus } \\
\text { nanoparticles) }\end{array}$ & Cathelicidin LL-37 & M. marinum & Axenic; macrophages & [168] \\
\hline NK-2 (plus nanoparticles) & $\begin{array}{l}\text { NK cells and cytotoxic } \\
\text { T cells }\end{array}$ & M. marinum & Axenic; macrophages & [168] \\
\hline HNP-1, 2 and 3 & Human neutrophils & M. avium & Axenic & [169] \\
\hline hLFcin1-11 and variants & Human lactoferricin & M. avium & Axenic & {$[170]$} \\
\hline LFcin17-30 and variants & Bovine lactoferricin & M. avium & Axenic; macrophages & {$[170,171]$} \\
\hline Mcdef & $\begin{array}{c}\text { Manila clams (Ruditapes } \\
\text { philippinarum) }\end{array}$ & M. fortuitum & Axenic & [172] \\
\hline NDBP-5.5 & Scorpion (Hadrurus gertschi) & M. abscessus & $\begin{array}{l}\text { Anexic; macrophages; } \\
\text { in vivo }\end{array}$ & [173] \\
\hline ToAP2 & Scorpion (Tityus obscurus) & M. massiliense & $\begin{array}{l}\text { Axenic; macrophages; } \\
\text { in vivo }\end{array}$ & [175] \\
\hline Polydim-I & Wasp (Polybia dimorpha) & M. abscessus & $\begin{array}{l}\text { Anexic; macrophages; } \\
\text { in vivo }\end{array}$ & [174] \\
\hline Polybia-MPII & $\begin{array}{l}\text { Mastoparans from wasp } \\
\text { (Pseudopolybia vespiceps) }\end{array}$ & $\begin{array}{l}\text { M. abscessus sp. } \\
\text { massiliense }\end{array}$ & Axenic; macrophages & [176] \\
\hline
\end{tabular}

\subsection{Bacteriophages}

The emergence of resistance to antibiotics has led to a shift of attention, once again, to the study of bacteriophages as a new strategy with which to combat infections caused by several types of bacteria, including NTM. Bacteriophages are viruses that infect and eventually lyse bacteria [177]. Although still with limitations [178], the use of bacteriophages has several potential advantages, not only as an alternative to conventional antibiotics, but also by working synergistically with them [179]. The fact that they are highly specific on a species or even serovar level makes phages unable to infect host cells, causing no harm to the patient $[178,179]$. As bacteriophages replicate inside the bacteria, the 
administered dose can be very low [178]. Besides that, their mode-of-action is much faster than that of antibiotics, and their action is not dependent on the bacterial metabolic state [179].

Bacteriophages are unable to penetrate eukaryotic cell membranes; thus, in the case of intracellular pathogens such as NTM, delivery systems are needed to give them access to the infection sites [178]. Liposomes have been used to carry bacteriophages into infected host cells. As an example, Neith et al. [180] successfully delivered the mycobacteriophage TM4 inside giant liposomes into monocytic THP-1 cells. In many studies, the nonvirulent species of mycobacteria M. smegmatis was used as a mycobacteriophage delivery system [181-183], since it naturally infects phagocytic cells that host virulent mycobacteria, while allowing, at the same time, the proliferation of the phages inside them [178]. The mycobacteriophage TM4 was effective against M. avium and Mtb in vitro [182] and in vivo [183], significantly reducing the number of bacilli. Broxmeyer et al. [182] also proved that the vacuoles containing $M$. smegmatis carrying TM4 fuse with $M$. avium-containing vacuoles in the macrophage, potentiating the effect of the mycobacteriophage. TM4 is only one example among more than 4200 bacteriophages known to infect mycobacteria [178]. More studies need to be carried out with NTM in order to understand which bacteriophages can infect each type of mycobacteria and their mechanism of action.

One way to overcome some of the limitations of bacteriophages, such as the difficulty to find specific phages for a certain type of bacteria, or the development of resistance [178], would be the administration of the bacteriophage-encoded enzymes which are responsible for bacterial lysis, i.e., endolysins. The use of endolysins as enzybiotics, i.e., enzyme-based antibiotics, has been gaining popularity as a new approach with which to combat bacterial antibiotic resistance [179]. The biological strategy of phages to infect bacteria, replicate inside them, and then cause bacterial lysis to release phage progeny, is based in a two-component holin-endolysin system. Holins are responsible for the depolarization of the cytoplasmatic membrane, creating pores that grant endolysins access to the peptidoglycan layer, and then degrading it [179]. Given the high lipidic nature of the mycobacterial cell wall, mycobacteriophages produce a hydrolase, LysA, that targets the peptidoglycan, but also LysB, an esterase that cleaves the linkage between the mycolic acids and arabinogalactan in the mycobacterial outer membrane [184]. Catalão et al. [185] isolated LysA and a shorter protein in the same reading frame from the mycobacteriophage Ms6, both with inhibitory activity against M. smegmatis, M. vaccae, M. aurum, and M. fortuitum. Grover et al. [186] reported that LysB isolated from the mycobacteriophage Bxz2 has 10-fold higher esterase activity than LysB isolated from the mycobacteriophage Ms6, but that both effectively inhibit the growth of M. smegmatis. Lai et al. [187] showed that LysA and LysB isolated from the mycobacteriophage BTCU-1, besides being active against $M$. smegmatis when administered exogenously, thereby causing severe modifications on the cell wall structure, also inhibited the viability of this mycobacterium growing inside RAW 264.7 macrophages. The promising results of these studies prove that an endolysin approach to treating mycobacterial infections can be applied in the future, also in combination with conventional antibiotics that target the mycobacterial cell wall. Studies specifically directed towards the most clinically-relevant NTM are warranted.

\subsection{Iron Chelators}

Similarly to other pathogenic bacteria, mycobacteria need iron for proliferation and for the establishment of infection [188]. They have actually evolved efficient strategies to acquire iron from the host, such as the synthesis and release of high-affinity siderophores, called mycobactins and carboxymycobactins. These siderophores are able to remove iron from host iron-binding proteins, such as transferrin and lactoferrin [189]. Additionally, M. tuberculosis can use haem as an iron source [190-192]. Iron is essential, not only because it is an important co-factor in the enzymes involved in bacterial growth, but also because it is needed for some virulence features. For example, the ability of $M$. avium to prevent phagosome maturation inside macrophages was shown to be dependent on its capacity to acquire iron [193]. Iron was also found to be necessary for biofilm formation by M. smegmatis [194,195], although this requirement has not been investigated in more clinically-relevant 
NTM. In agreement with these observations, $M$. tuberculosis with mutations in the proteins involved in iron acquisition was found to exhibit a lower growth in macrophages and also a lower level of virulence in mice [190,196,197].

Given that pathogens fundamentally need iron to survive and proliferate, iron chelators have been suggested as a plausible strategy to treat infections, including mycobacteriosis [198]. We have previously shown that the addition of iron chelators to $M$. avium, in axenic cultures, in macrophage cultures, or in vivo, led to significant decreases in mycobacterial growth [199,200]. Furthermore, we have developed new molecules based on the 3-hydroxy-4-pyridinone iron-chelating moiety, in which the inclusion of a rhodamine residue improved antimycobacterial activity, presumably through improved intracellular distribution and targeting for the mycobacteria-containing phagosome [201,202]. Interestingly, these iron chelators had synergistic activity with ethambutol in decreasing M. avium growth inside macrophages [203]. Curiously, in a study aimed at the characterization of the antimicrobial effect of ATP, the authors claimed that ATP inhibits the growth of MAC through iron chelation [204]. In another study, also aimed at the identification of the mechanism of antimycobacterial action of the newly-developed drug PZP, the authors found that it decreases bacterial growth through iron chelation [205].

Given the host's need for iron for their own metabolic needs, one important concern related to iron chelation therapies is the development of adequate cell-targeting strategies that may guarantee iron depletion in the pathogen without a concomitant deficiency in the host [198]. From the data available so far, chelators alone don't seem to exhibit a strong enough antimycobacterial activity, but they may have a role as an adjunct therapy, together with conventional antibiotics.

\subsection{Host-Directed Therapies}

Traditional antibiotics act directly on the pathogen by killing or inhibiting its growth. However, by targeting the host factors necessary for the bacteria to survive or replicate, it is possible to control the infection without inducing bacterial resistance and, at the same time, to minimize the dosage of traditional agents [206,207]. Host-directed therapies (HDT) can modulate specific pathways or mechanisms, stimulating, for instance, the host immune system to more efficiently combat the infection, or reducing the symptoms caused by exacerbated inflammation [206,207].

As previously mentioned, an immune response based on IFN- $\gamma$ producing $\mathrm{T}$ cells is very important to control mycobacterial infections. Several studies in mouse models have shown that the manipulation of the immune response may improve infection outcomes. Exogenous administration of recombinant IL-12 enhanced the production of IFN- $\gamma$ in immunocompetent and immunodeficient SCID or CD4-depleted mice, which conferred protection against some strains of M. avium [208]. Also, MAC-infected BALB/c mice injected with IL-18-encoding DNA significantly decreased the bacterial load in the lung through the persistent production of IFN- $\gamma$ for 8 weeks [209]. On the other hand, the TNF- $\alpha$ inhibitor etanercept, together with conventional antibiotics against TB, significantly decreased the bacterial burden in the lung of Mtb-infected mice, in comparison with treatment with antibiotics alone [210]. There are, however, several studies demonstrating that patients with chronic inflammatory diseases that are treated with TNF- $\alpha$ inhibitors have a higher risk of TB reactivation or NTM disease [211,212]. Besides being one of the major macrophage-activating cytokines [27], TNF- $\alpha$ is essential to maintaining mycobacteria contained in solid, well-defined granulomas in the host lungs, preventing it from infecting other organs [213,214]. However, exaggerated levels of this cytokine are deleterious, as it induces hyperinflammation and the disorganization of granulomas [213]. When considering HDT that interferes in the TNF- $\alpha$ pathway, all these factors must be taken into account.

More recent studies have tried to understand the cause behind attenuated cellular immunity in humans upon infection with mycobacteria. For example, Shu et al. [215] studied 50 patients with MAC lung disease, and compared the response of their peripheral blood mononuclear cells (PBMCs) to MAC antigen stimulation with that of 30 healthy controls. The stimulated PBMCs of patients with MAC lung disease expressed less IFN- $\gamma$ compared to the healthy controls, but both groups 
expressed high levels of the receptor programmed cell death-1 (PD-1) and its ligand. PD-1 promotes apoptosis of antigen-specific $T$ cells, attenuating cellular immunity, which allows the infection to progress [216]. By blocking PD-1 and PD ligand with antagonizing antibodies, Shu et al. observed reduced lymphocyte apoptosis and increased production of IFN- $\gamma$ in cells in both study groups [215]. The authors thus suggest that the PD-1 pathway is an interesting target for HDT, with potential to treat MAC lung disease.

Rather than interfering with systemic immune response, HDT directed to NTM probably relies on the macrophage-intrinsic pathways of bacterial killing. In that direction, an interesting target is autophagy. Autophagy may be triggered by nutrient starvation, when cells reduce mTOR signaling, promoting the digestion of cellular components in autolysosomes [217,218]. But the presence of intracellular pathogens also induces autophagy. This results in the isolation of the pathogen inside autophagosomes, which are fused with lysosomes, resulting in the digestion of the pathogen and the induction of an adaptive immune response [217]. Given the fact that mycobacteria naturally inhibit the phagosome-lysosome fusion [24], the induction of autophagy is an appealing target to HDT [207]. Studies done with nonpathogenic mycobacteria have yielded contradictory results, and it is not clear whether mycobacteria induce or inhibit macrophage autophagy, and what the role of this process is in mycobacterial growth containment. [217,219]. Anticonvulsant drugs, EGFR inhibitors, and even the role of vitamin D in promoting autophagy have been studied against Mtb [207]. In M. avium, lactoferricin, in particular, the D-enantiomer of LFcin17-30, leads to the intramacrophagic death of the mycobacteria by inducing phagosomal maturation and autophagy, with increased lysosomes and autophagosomes [171]. More studies must be performed to find an HDT target, perhaps in the autophagy pathway, which can overcome the mechanism of the arrest of phagosome maturation by NTM.

\section{Concluding Remarks}

Infectious diseases continue to pose a heavy burden on public health systems worldwide. NTM were, for a long time, considered nonpathogenic or rare opportunistic agents. However, the incidence of disease by these agents is rising, and is revealing the medical community to be devoid of validated, efficient therapeutic weapons to fight them. With this review, we hope to stimulate researchers in the area of drug development to test atypical therapeutic agents against NTM, in an effort to put forward new, efficient alternatives with which to treat these devastating diseases.

Author Contributions: C.M.B. made the original draft preparation. All authors reviewed and edited the manuscript. All authors have read and agreed to the published version of the manuscript.

Funding: The work of the authors is financed by National Portuguese funds through FCT-Fundação para a Ciência e a Tecnologia/Ministério da Ciência, Tecnologia e Ensino Superior in the framework of the projects PTDC/IMI-MIC/1683/2014 and PTDC/BTM-SAL/29786/2017.

Conflicts of Interest: The authors declare no conflict of interest.

\section{References}

1. Anonymous. Diagnosis and treatment of disease caused by nontuberculous mycobacteria. This official statement of the American Thoracic Society was approved by the Board of Directors, March 1997. Medical Section of the American Lung Association. Am. J. Respir. Crit. Care Med. 1997, 156, S1-S25. [CrossRef]

2. Wolinsky, E. Nontuberculous mycobacteria and associated diseases. Am. Rev. Respir. Dis. 1979, 119, $107-159$. [CrossRef] [PubMed]

3. Cowman, S.; van Ingen, J.; Griffith, D.E.; Loebinger, M.R. Non-tuberculous mycobacterial pulmonary disease. Eur. Respir. J. 2019, 54. [CrossRef] [PubMed] 
4. Griffith, D.E.; Aksamit, T.; Brown-Elliott, B.A.; Catanzaro, A.; Daley, C.; Gordin, F.; Holland, S.M.; Horsburgh, R.; Huitt, G.; Iademarco, M.F.; et al. An official ATS/IDSA statement: Diagnosis, treatment, and prevention of nontuberculous mycobacterial diseases. Am. J. Respir. Crit. Care Med. 2007, 175, 367-416. [CrossRef] [PubMed]

5. Prevots, D.R.; Marras, T.K. Epidemiology of human pulmonary infection with nontuberculous mycobacteria: A review. Clin. Chest Med. 2015, 36, 13-34. [CrossRef] [PubMed]

6. Adjemian, J.; Daniel-Wayman, S.; Ricotta, E.; Prevots, D.R. Epidemiology of Nontuberculous Mycobacteriosis. Semin. Respir. Crit. Care Med. 2018, 39, 325-335. [CrossRef] [PubMed]

7. Drummond, W.K.; Kasperbauer, S.H. Nontuberculous Mycobacteria: Epidemiology and the Impact on Pulmonary and Cardiac Disease. Thorac. Surg. Clin. 2019, 29, 59-64. [CrossRef] [PubMed]

8. Adjemian, J.; Olivier, K.N.; Seitz, A.E.; Falkinham, J.O., 3rd; Holland, S.M.; Prevots, D.R. Spatial clusters of nontuberculous mycobacterial lung disease in the United States. Am. J. Respir. Crit. Care Med. 2012, 186, 553-558. [CrossRef] [PubMed]

9. Adjemian, J.; Olivier, K.N.; Seitz, A.E.; Holland, S.M.; Prevots, D.R. Prevalence of nontuberculous mycobacterial lung disease in U.S. Medicare beneficiaries. Am. J. Respir. Crit. Care Med. 2012, 185, 881-886. [CrossRef]

10. Nishiuchi, Y.; Iwamoto, T.; Maruyama, F. Infection Sources of a Common Non-tuberculous Mycobacterial Pathogen, Mycobacterium avium Complex. Front. Med. (Lausanne) 2017, 4, 27. [CrossRef]

11. Feazel, L.M.; Baumgartner, L.K.; Peterson, K.L.; Frank, D.N.; Harris, J.K.; Pace, N.R. Opportunistic pathogens enriched in showerhead biofilms. Proc. Natl. Acad. Sci. USA 2009, 106, 16393-16399. [CrossRef] [PubMed]

12. Esteban, J.; Garcia-Coca, M. Mycobacterium Biofilms. Front. Microbiol. 2017, 8, 2651. [CrossRef] [PubMed]

13. Brode, S.K.; Daley, C.L.; Marras, T.K. The epidemiologic relationship between tuberculosis and non-tuberculous mycobacterial disease: A systematic review. Int. J. Tuberc. Lung Dis. 2014, 18, 1370-1377. [CrossRef] [PubMed]

14. Prevots, D.R.; Shaw, P.A.; Strickland, D.; Jackson, L.A.; Raebel, M.A.; Blosky, M.A.; Montes de Oca, R.; Shea, Y.R.; Seitz, A.E.; Holland, S.M.; et al. Nontuberculous mycobacterial lung disease prevalence at four integrated health care delivery systems. Am. J. Respir. Crit. Care Med. 2010, 182, 970-976. [CrossRef]

15. Horsburgh, C.R., Jr.; Hanson, D.L.; Jones, J.L.; Thompson, S.E., 3rd. Protection from Mycobacterium avium complex disease in human immunodeficiency virus-infected persons with a history of tuberculosis. J. Infect. Dis. 1996, 174, 1212-1217. [CrossRef]

16. Gebert, M.J.; Delgado-Baquerizo, M.; Oliverio, A.M.; Webster, T.M.; Nichols, L.M.; Honda, J.R.; Chan, E.D.; Adjemian, J.; Dunn, R.R.; Fierer, N. Ecological Analyses of Mycobacteria in Showerhead Biofilms and Their Relevance to Human Health. MBio 2018, 9. [CrossRef]

17. Nishiuchi, Y.; Maekura, R.; Kitada, S.; Tamaru, A.; Taguri, T.; Kira, Y.; Hiraga, T.; Hirotani, A.; Yoshimura, K.; Miki, M.; et al. The recovery of Mycobacterium avium-intracellulare complex (MAC) from the residential bathrooms of patients with pulmonary MAC. Clin. Infect. Dis. 2007, 45, 347-351. [CrossRef]

18. Falkinham, J.O., 3rd; Iseman, M.D.; de Haas, P.; van Soolingen, D. Mycobacterium avium in a shower linked to pulmonary disease. J. Water Health 2008, 6, 209-213. [CrossRef]

19. Bryant, J.M.; Grogono, D.M.; Rodriguez-Rincon, D.; Everall, I.; Brown, K.P.; Moreno, P.; Verma, D.; Hill, E.; Drijkoningen, J.; Gilligan, P.; et al. Emergence and spread of a human-transmissible multidrug-resistant nontuberculous mycobacterium. Science 2016, 354, 751-757. [CrossRef]

20. Lopez-Varela, E.; Garcia-Basteiro, A.L.; Santiago, B.; Wagner, D.; van Ingen, J.; Kampmann, B. Non-tuberculous mycobacteria in children: Muddying the waters of tuberculosis diagnosis. Lancet Respir. Med. 2015, 3, 244-256. [CrossRef]

21. Daffe, M. The cell envelope of tubercle bacilli. Tuberculosis 2015, 95 (Suppl. 1), S155-S158. [CrossRef] [PubMed]

22. Vilcheze, C.; Kremer, L. Acid-Fast Positive and Acid-Fast Negative Mycobacterium tuberculosis: The Koch Paradox. Microbiol. Spectr. 2017, 5. [CrossRef]

23. Gomes, M.S.; Paul, S.; Moreira, A.L.; Appelberg, R.; Rabinovitch, M.; Kaplan, G. Survival of Mycobacterium avium and Mycobacterium tuberculosis in acidified vacuoles of murine macrophages. Infect. Immun. 1999, 67, 3199-3206. [CrossRef] [PubMed] 
24. Frehel, C.; de Chastellier, C.; Lang, T.; Rastogi, N. Evidence for inhibition of fusion of lysosomal and prelysosomal compartments with phagosomes in macrophages infected with pathogenic Mycobacterium avium. Infect. Immun. 1986, 52, 252-262. [CrossRef] [PubMed]

25. Guirado, E.; Schlesinger, L.S.; Kaplan, G. Macrophages in tuberculosis: Friend or foe. Semin. Immunopathol. 2013, 35, 563-583. [CrossRef] [PubMed]

26. Fratti, R.A.; Chua, J.; Vergne, I.; Deretic, V. Mycobacterium tuberculosis glycosylated phosphatidylinositol causes phagosome maturation arrest. Proc. Natl. Acad. Sci. USA 2003, 100, 5437-5442. [CrossRef] [PubMed]

27. Appelberg, R. Pathogenesis of Mycobacterium avium infection: Typical responses to an atypical mycobacterium? Immunol. Res. 2006, 35, 179-190. [CrossRef]

28. Gomes, M.S.; Appelberg, R. NRAMP1- or cytokine-induced bacteriostasis of Mycobacterium avium by mouse macrophages is independent of the respiratory burst. Microbiology 2002, 148, 3155-3160. [CrossRef]

29. Appelberg, R. Macrophage nutriprive antimicrobial mechanisms. J. Leukoc. Biol. 2006, 79, 1117-1128. [CrossRef]

30. Early, J.; Fischer, K.; Bermudez, L.E. Mycobacterium avium uses apoptotic macrophages as tools for spreading. Microb. Pathog. 2011, 50, 132-139. [CrossRef]

31. Thegerstrom, J.; Jonsson, B.; Brudin, L.; Olsen, B.; Wold, A.E.; Ernerudh, J.; Friman, V. Mycobacterium avium subsp. avium and subsp. hominissuis give different cytokine responses after in vitro stimulation of human blood mononuclear cells. PLoS ONE 2012, 7, e34391. [CrossRef] [PubMed]

32. Donovan, M.L.; Schultz, T.E.; Duke, T.J.; Blumenthal, A. Type I Interferons in the Pathogenesis of Tuberculosis: Molecular Drivers and Immunological Consequences. Front. Immunol. 2017, 8, 1633. [CrossRef]

33. Abel, L.; Fellay, J.; Haas, D.W.; Schurr, E.; Srikrishna, G.; Urbanowski, M.; Chaturvedi, N.; Srinivasan, S.; Johnson, D.H.; Bishai, W.R. Genetics of human susceptibility to active and latent tuberculosis: Present knowledge and future perspectives. Lancet Infect. Dis. 2018, 18, e64-e75. [CrossRef]

34. Loddenkemper, R.; Lipman, M.; Zumla, A. Clinical Aspects of Adult Tuberculosis. Cold Spring Harb. Perspect. Med. 2015, 6, a017848. [CrossRef] [PubMed]

35. Griffith, D.E. Therapy of nontuberculous mycobacterial disease. Curr. Opin. Infect. Dis. 2007, 20, $198-203$. [CrossRef] [PubMed]

36. Haworth, C.S.; Banks, J.; Capstick, T.; Fisher, A.J.; Gorsuch, T.; Laurenson, I.F.; Leitch, A.; Loebinger, M.R.; Milburn, H.J.; Nightingale, M.; et al. British Thoracic Society guidelines for the management of non-tuberculous mycobacterial pulmonary disease (NTM-PD). Thorax 2017, 72, ii1-ii64. [CrossRef]

37. Brown-Elliott, B.A.; Nash, K.A.; Wallace, R.J., Jr. Antimicrobial susceptibility testing, drug resistance mechanisms, and therapy of infections with nontuberculous mycobacteria. Clin. Microbiol. Rev. 2012, 25, 545-582. [CrossRef]

38. Brode, S.K.; Chung, H.; Campitelli, M.A.; Kwong, J.C.; Marchand-Austin, A.; Winthrop, K.L.; Jamieson, F.B.; Marras, T.K. Prescribing Patterns for Treatment of Mycobacterium avium Complex and M. xenopi Pulmonary Disease in Ontario, Canada, 2001-2013. Emerg. Infect. Dis. 2019, 25, 1271-1280. [CrossRef]

39. Adjemian, J.; Prevots, D.R.; Gallagher, J.; Heap, K.; Gupta, R.; Griffith, D. Lack of adherence to evidence-based treatment guidelines for nontuberculous mycobacterial lung disease. Ann. Am. Thorac. Soc. 2014, 11, 9-16. [CrossRef]

40. Diel, R.; Jacob, J.; Lampenius, N.; Loebinger, M.; Nienhaus, A.; Rabe, K.F.; Ringshausen, F.C. Burden of non-tuberculous mycobacterial pulmonary disease in Germany. Eur. Respir. J. 2017, 49, 1602109. [CrossRef]

41. van Ingen, J.; Wagner, D.; Gallagher, J.; Morimoto, K.; Lange, C.; Haworth, C.S.; Floto, R.A.; Adjemian, J.; Prevots, D.R.; Griffith, D.E.; et al. Poor adherence to management guidelines in nontuberculous mycobacterial pulmonary diseases. Eur. Respir. J. 2017, 49, 1601855. [CrossRef] [PubMed]

42. Ricotta, E.E.; Olivier, K.N.; Lai, Y.L.; Prevots, D.R.; Adjemian, J. Hospital-based antibiotic use in patients with Mycobacterium avium complex. ERJ Open Res. 2018, 4, 00109-2018. [CrossRef] [PubMed]

43. Griffith, D.E. Treatment of Mycobacterium avium Complex (MAC). Semin. Respir. Crit. Care Med. 2018, 39, 351-361. [CrossRef] [PubMed]

44. Egelund, E.F.; Fennelly, K.P.; Peloquin, C.A. Medications and monitoring in nontuberculous mycobacteria infections. Clin. Chest Med. 2015, 36, 55-66. [CrossRef]

45. TB Alliance. Clarithromycin. Tuberculosis 2008, 88, 92-95. [CrossRef]

46. Philley, J.V.; Griffith, D.E. Treatment of slowly growing mycobacteria. Clin. Chest Med. 2015, 36, 79-90. [CrossRef] 
47. Lakshminarayana, S.B.; Huat, T.B.; Ho, P.C.; Manjunatha, U.H.; Dartois, V.; Dick, T.; Rao, S.P. Comprehensive physicochemical, pharmacokinetic and activity profiling of anti-TB agents. J. Antimicrob. Chemother. 2015, 70, 857-867. [CrossRef]

48. Prideaux, B.; Via, L.E.; Zimmerman, M.D.; Eum, S.; Sarathy, J.; O’Brien, P.; Chen, C.; Kaya, F.; Weiner, D.M.; Chen, P.Y.; et al. The association between sterilizing activity and drug distribution into tuberculosis lesions. Nat. Med. 2015, 21, 1223-1227. [CrossRef]

49. TB Alliance. Rifabutin. Tuberculosis 2008, 88, 145-147. [CrossRef]

50. Ganapathy, U.S.; Dartois, V.; Dick, T. Repositioning rifamycins for Mycobacterium abscessus lung disease. Expert Opin. Drug Discov. 2019, 14, 867-878. [CrossRef]

51. Aziz, D.B.; Low, J.L.; Wu, M.L.; Gengenbacher, M.; Teo, J.W.P.; Dartois, V.; Dick, T. Rifabutin Is Active against Mycobacterium abscessus Complex. Antimicrob. Agents Chemother. 2017, 61, e00155-17. [CrossRef] [PubMed]

52. Brown-Elliott, B.A.; Iakhiaeva, E.; Griffith, D.E.; Woods, G.L.; Stout, J.E.; Wolfe, C.R.; Turenne, C.Y.; Wallace, R.J., Jr. In vitro activity of amikacin against isolates of Mycobacterium avium complex with proposed MIC breakpoints and finding of a $16 \mathrm{~S}$ rRNA gene mutation in treated isolates. J. Clin. Microbiol. 2013, 51, 3389-3394. [CrossRef] [PubMed]

53. Griffith, D.E.; Eagle, G.; Thomson, R.; Aksamit, T.R.; Hasegawa, N.; Morimoto, K.; Addrizzo-Harris, D.J.; O'Donnell, A.E.; Marras, T.K.; Flume, P.A.; et al. Amikacin Liposome Inhalation Suspension for Treatment-Refractory Lung Disease Caused by Mycobacterium avium Complex (CONVERT). A Prospective, Open-Label, Randomized Study. Am. J. Respir. Crit. Care Med. 2018, 198, 1559-1569. [CrossRef] [PubMed]

54. Philley, J.V.; Griffith, D.E. Medical Management of Pulmonary Nontuberculous Mycobacterial Disease. Thorac. Surg Clin. 2019, 29, 65-76. [CrossRef] [PubMed]

55. Lange, C.; Dheda, K.; Chesov, D.; Mandalakas, A.M.; Udwadia, Z.; Horsburgh, C.R., Jr. Management of drug-resistant tuberculosis. Lancet 2019, 394, 953-966. [CrossRef]

56. Smith, C.S.; Aerts, A.; Saunderson, P.; Kawuma, J.; Kita, E.; Virmond, M. Multidrug therapy for leprosy: A game changer on the path to elimination. Lancet Infect. Dis. 2017, 17, e293-e297. [CrossRef]

57. Martiniano, S.L.; Wagner, B.D.; Levin, A.; Nick, J.A.; Sagel, S.D.; Daley, C.L. Safety and Effectiveness of Clofazimine for Primary and Refractory Nontuberculous Mycobacterial Infection. Chest 2017, 152, 800-809. [CrossRef]

58. Yang, B.; Jhun, B.W.; Moon, S.M.; Lee, H.; Park, H.Y.; Jeon, K.; Kim, D.H.; Kim, S.Y.; Shin, S.J.; Daley, C.L.; et al. Clofazimine-Containing Regimen for the Treatment of Mycobacterium abscessus Lung Disease. Antimicrob. Agents Chemother. 2017, 61, e02052-16. [CrossRef]

59. Field, S.K.; Cowie, R.L. Treatment of Mycobacterium avium-intracellulare complex lung disease with a macrolide, ethambutol, and clofazimine. Chest 2003, 124, 1482-1486. [CrossRef]

60. Jarand, J.; Davis, J.P.; Cowie, R.L.; Field, S.K.; Fisher, D.A. Long-term Follow-up of Mycobacterium avium Complex Lung Disease in Patients Treated With Regimens Including Clofazimine and/or Rifampin. Chest 2016, 149, 1285-1293. [CrossRef]

61. van Ingen, J.; Totten, S.E.; Helstrom, N.K.; Heifets, L.B.; Boeree, M.J.; Daley, C.L. In vitro synergy between clofazimine and amikacin in treatment of nontuberculous mycobacterial disease. Antimicrob. Agents Chemother. 2012, 56, 6324-6327. [CrossRef] [PubMed]

62. Shen, G.H.; Wu, B.D.; Hu, S.T.; Lin, C.F.; Wu, K.M.; Chen, J.H. High efficacy of clofazimine and its synergistic effect with amikacin against rapidly growing mycobacteria. Int. J. Antimicrob. Agents 2010, 35, 400-404. [CrossRef] [PubMed]

63. Ruth, M.M.; Sangen, J.J.N.; Remmers, K.; Pennings, L.J.; Svensson, E.; Aarnoutse, R.E.; Zweijpfenning, S.M.H.; Hoefsloot, W.; Kuipers, S.; Magis-Escurra, C.; et al. A bedaquiline/clofazimine combination regimen might add activity to the treatment of clinically relevant non-tuberculous mycobacteria. J. Antimicrob. Chemother. 2019, 74, 935-943. [CrossRef] [PubMed]

64. Huang, C.C.; Wu, M.F.; Chen, H.C.; Huang, W.C. In vitro activity of aminoglycosides, clofazimine, $\mathrm{d}$-cycloserine and dapsone against 83 Mycobacterium avium complex clinical isolates. J. Microbiol. Immunol. Infect. 2018, 51, 636-643. [CrossRef] [PubMed]

65. Leach, K.L.; Brickner, S.J.; Noe, M.C.; Miller, P.F. Linezolid, the first oxazolidinone antibacterial agent. Ann. N. Y. Acad. Sci. 2011, 1222, 49-54. [CrossRef] [PubMed] 
66. Winthrop, K.L.; Ku, J.H.; Marras, T.K.; Griffith, D.E.; Daley, C.L.; Olivier, K.N.; Aksamit, T.R.; Varley, C.D.; Mackey, K.; Prevots, D.R. The tolerability of linezolid in the treatment of nontuberculous mycobacterial disease. Eur. Respir. J. 2015, 45, 1177-1179. [CrossRef] [PubMed]

67. Zhao, W.; Jiang, Y.; Bao, P.; Li, Y.; Tang, L.; Zhou, Y.; Zhao, Y. Evaluation of the Efficacy of Novel Oxazolidinone Analogues against Nontuberculous Mycobacteria In Vitro. Jpn. J. Infect. Dis. 2015, 68, 520-522. [CrossRef]

68. Brown-Elliott, B.A.; Wallace, R.J., Jr. In Vitro Susceptibility Testing of Tedizolid against Nontuberculous Mycobacteria. J. Clin. Microbiol. 2017, 55, 1747-1754. [CrossRef]

69. Vera-Cabrera, L.; Brown-Elliott, B.A.; Wallace, R.J., Jr.; Ocampo-Candiani, J.; Welsh, O.; Choi, S.H.; Molina-Torres, C.A. In vitro activities of the novel oxazolidinones DA-7867 and DA-7157 against rapidly and slowly growing mycobacteria. Antimicrob. Agents Chemother. 2006, 50, 4027-4029. [CrossRef]

70. Kim, T.S.; Choe, J.H.; Kim, Y.J.; Yang, C.S.; Kwon, H.J.; Jeong, J.; Kim, G.; Park, D.E.; Jo, E.K.; Cho, Y.L.; et al. Activity of LCB01-0371, a Novel Oxazolidinone, against Mycobacterium abscessus. Antimicrob. Agents Chemother. 2017, 61, e02752-16. [CrossRef]

71. Deshpande, D.; Srivastava, S.; Pasipanodya, J.G.; Gumbo, T. Linezolid as treatment for pulmonary Mycobacterium avium disease. J. Antimicrob. Chemother. 2017, 72, i24-i29. [CrossRef] [PubMed]

72. Wallace, R.J., Jr.; Brown-Elliott, B.A.; Ward, S.C.; Crist, C.J.; Mann, L.B.; Wilson, R.W. Activities of linezolid against rapidly growing mycobacteria. Antimicrob. Agents Chemother. 2001, 45, 764-767. [CrossRef] [PubMed]

73. Cavusoglu, C.; Soyler, I.; Akinci, P. Activities of Linezolid against nontuberculous mycobacteria. New Microbiol. 2007, 30, 411-414.

74. Brown-Elliott, B.A.; Wallace, R.J., Jr.; Blinkhorn, R.; Crist, C.J.; Mann, L.B. Successful treatment of disseminated Mycobacterium chelonae infection with linezolid. Clin. Infect. Dis. 2001, 33, 1433-1434. [CrossRef] [PubMed]

75. Kyle, S.D.; Porter, W.M. Mycobacterium chelonae infection successfully treated with oral clarithromycin and linezolid. Br. J. Dermatol. 2004, 151, 1101. [CrossRef] [PubMed]

76. Inoue, T.; Tsunoda, A.; Nishimoto, E.; Nishida, K.; Komatsubara, Y.; Onoe, R.; Saji, J.; Mineshita, M. Successful use of linezolid for refractory Mycobacterium abcessus infection: A case report. Respir. Med. Case Rep. 2018, 23, 43-45. [CrossRef] [PubMed]

77. Bostan, C.; Slim, E.; Choremis, J.; Boutin, T.; Brunette, I.; Mabon, M.; Talajic, J.C. Successful management of severe post-LASIK Mycobacterium abscessus keratitis with topical amikacin and linezolid, flap ablation, and topical corticosteroids. J. Cataract. Refract. Surg. 2019, 45, 1032-1035. [CrossRef]

78. Yasar, K.K.; Pehlivanoglu, F.; Sengoz, G.; Cabioglu, N. Successfully treated Mycobacterium abscessus mastitis: A rare cause of breast masses. Indian J. Med. Microbiol. 2011, 29, 425-427. [CrossRef]

79. Diacon, A.H.; Pym, A.; Grobusch, M.P.; de los Rios, J.M.; Gotuzzo, E.; Vasilyeva, I.; Leimane, V.; Andries, K.; Bakare, N.; De Marez, T.; et al. Multidrug-resistant tuberculosis and culture conversion with bedaquiline. N. Engl. J. Med. 2014, 371, 723-732. [CrossRef]

80. Diacon, A.H.; Pym, A.; Grobusch, M.; Patientia, R.; Rustomjee, R.; Page-Shipp, L.; Pistorius, C.; Krause, R.; Bogoshi, M.; Churchyard, G.; et al. The diarylquinoline TMC207 for multidrug-resistant tuberculosis. N. Engl. J. Med. 2009, 360, 2397-2405. [CrossRef]

81. TB Alliance. Tmc-207. Tuberculosis 2008, 88, 168-169. [CrossRef]

82. Martin, A.; Godino, I.T.; Aguilar-Ayala, D.A.; Mathys, V.; Lounis, N.; Villalobos, H.R. In vitro activity of bedaquiline against slow-growing nontuberculous mycobacteria. J. Med. Microbiol. 2019, 68, 1137-1139. [CrossRef] [PubMed]

83. Kim, D.H.; Jhun, B.W.; Moon, S.M.; Kim, S.Y.; Jeon, K.; Kwon, O.J.; Huh, H.J.; Lee, N.Y.; Shin, S.J.; Daley, C.L.; et al. In Vitro Activity of Bedaquiline and Delamanid against Nontuberculous Mycobacteria, Including Macrolide-Resistant Clinical Isolates. Antimicrob. Agents Chemother. 2019, 63. [CrossRef] [PubMed]

84. Aguilar-Ayala, D.A.; Cnockaert, M.; Andre, E.; Andries, K.; Gonzalez, Y.M.J.A.; Vandamme, P.; Palomino, J.C.; Martin, A. In vitro activity of bedaquiline against rapidly growing nontuberculous mycobacteria. J. Med. Microbiol. 2017, 66, 1140-1143. [CrossRef] [PubMed]

85. Li, B.; Ye, M.; Guo, Q.; Zhang, Z.; Yang, S.; Ma, W.; Yu, F.; Chu, H. Determination of MIC Distribution and Mechanisms of Decreased Susceptibility to Bedaquiline among Clinical Isolates of Mycobacterium abscessus. Antimicrob. Agents Chemother. 2018, 62. [CrossRef] [PubMed]

86. Pang, Y.; Zheng, H.; Tan, Y.; Song, Y.; Zhao, Y. In Vitro Activity of Bedaquiline against Nontuberculous Mycobacteria in China. Antimicrob. Agents Chemother. 2017, 61. [CrossRef] 
87. Dupont, C.; Viljoen, A.; Thomas, S.; Roquet-Baneres, F.; Herrmann, J.L.; Pethe, K.; Kremer, L. Bedaquiline Inhibits the ATP Synthase in Mycobacterium abscessus and Is Effective in Infected Zebrafish. Antimicrob. Agents Chemother. 2017, 61. [CrossRef]

88. Brown-Elliott, B.A.; Wallace, R.J., Jr. In Vitro Susceptibility Testing of Bedaquiline against Mycobacterium abscessus Complex. Antimicrob. Agents Chemother. 2019, 63. [CrossRef]

89. Brown-Elliott, B.A.; Philley, J.V.; Griffith, D.E.; Thakkar, F.; Wallace, R.J., Jr. In Vitro Susceptibility Testing of Bedaquiline against Mycobacterium avium Complex. Antimicrob. Agents Chemother. 2017, 61. [CrossRef]

90. Yu, X.; Gao, X.; Li, C.; Luo, J.; Wen, S.; Zhang, T.; Ma, Y.; Dong, L.; Wang, F.; Huang, H. In Vitro Activities of Bedaquiline and Delamanid against Nontuberculous Mycobacteria Isolated in Beijing, China. Antimicrob. Agents Chemother. 2019, 63. [CrossRef]

91. Lerat, I.; Cambau, E.; Roth Dit Bettoni, R.; Gaillard, J.L.; Jarlier, V.; Truffot, C.; Veziris, N. In vivo evaluation of antibiotic activity against Mycobacterium abscessus. J. Infect. Dis. 2014, 209, 905-912. [CrossRef] [PubMed]

92. Lounis, N.; Gevers, T.; Van den Berg, J.; Vranckx, L.; Andries, K. ATP synthase inhibition of Mycobacterium avium is not bactericidal. Antimicrob. Agents Chemother. 2009, 53, 4927-4929. [CrossRef] [PubMed]

93. Obregon-Henao, A.; Arnett, K.A.; Henao-Tamayo, M.; Massoudi, L.; Creissen, E.; Andries, K.; Lenaerts, A.J.; Ordway, D.J. Susceptibility of Mycobacterium abscessus to antimycobacterial drugs in preclinical models. Antimicrob. Agents Chemother. 2015, 59, 6904-6912. [CrossRef] [PubMed]

94. Philley, J.V.; Wallace, R.J., Jr.; Benwill, J.L.; Taskar, V.; Brown-Elliott, B.A.; Thakkar, F.; Aksamit, T.R.; Griffith, D.E. Preliminary Results of Bedaquiline as Salvage Therapy for Patients With Nontuberculous Mycobacterial Lung Disease. Chest 2015, 148, 499-506. [CrossRef]

95. Alexander, D.C.; Vasireddy, R.; Vasireddy, S.; Philley, J.V.; Brown-Elliott, B.A.; Perry, B.J.; Griffith, D.E.; Benwill, J.L.; Cameron, A.D.; Wallace, R.J., Jr. Emergence of mmpT5 Variants during Bedaquiline Treatment of Mycobacterium intracellulare Lung Disease. J. Clin. Microbiol. 2017, 55, 574-584. [CrossRef]

96. Lindman, M.; Dick, T. Bedaquiline Eliminates Bactericidal Activity of beta-Lactams against Mycobacterium abscessus. Antimicrob. Agents Chemother. 2019, 63. [CrossRef]

97. Svensson, E.M.; Murray, S.; Karlsson, M.O.; Dooley, K.E. Rifampicin and rifapentine significantly reduce concentrations of bedaquiline, a new anti-TB drug. J. Antimicrob. Chemother. 2015, 70, 1106-1114. [CrossRef]

98. Liu, Y.; Matsumoto, M.; Ishida, H.; Ohguro, K.; Yoshitake, M.; Gupta, R.; Geiter, L.; Hafkin, J. Delamanid: From discovery to its use for pulmonary multidrug-resistant tuberculosis (MDR-TB). Tuberculosis 2018, 111, 20-30. [CrossRef]

99. Krieger, D.; Schonfeld, N.; Vesenbeckh, S.; Bettermann, G.; Bauer, T.T.; Russmann, H.; Mauch, H. Is delamanid a potential agent in the treatment of diseases caused by Mycobacterium avium-intracellulare? Eur. Respir. J. 2016, 48, 1803-1804. [CrossRef]

100. Pandey, R.; Chen, L.; Manca, C.; Jenkins, S.; Glaser, L.; Vinnard, C.; Stone, G.; Lee, J.; Mathema, B.; Nuermberger, E.L.; et al. Dual beta-Lactam Combinations Highly Active against Mycobacterium abscessus Complex In Vitro. MBio 2019, 10, e02895-18. [CrossRef]

101. Story-Roller, E.; Maggioncalda, E.C.; Lamichhane, G. Select beta-Lactam Combinations Exhibit Synergy against Mycobacterium abscessus In Vitro. Antimicrob. Agents Chemother. 2019, 63, e02613-18. [CrossRef] [PubMed]

102. Story-Roller, E.; Maggioncalda, E.C.; Lamichhane, G. Synergistic Efficacy of beta-Lactam Combinations against Mycobacterium abscessus Pulmonary Infection in Mice. Antimicrob. Agents Chemother. 2019, 63, e00614-19. [CrossRef] [PubMed]

103. Kaushik, A.; Ammerman, N.C.; Lee, J.; Martins, O.; Kreiswirth, B.N.; Lamichhane, G.; Parrish, N.M.; Nuermberger, E.L. In Vitro Activity of the New beta-Lactamase Inhibitors Relebactam and Vaborbactam in Combination with beta-Lactams against Mycobacterium abscessus Complex Clinical Isolates. Antimicrob. Agents Chemother. 2019, 63, e02623-18. [CrossRef] [PubMed]

104. Kaushik, A.; Gupta, C.; Fisher, S.; Story-Roller, E.; Galanis, C.; Parrish, N.; Lamichhane, G. Combinations of avibactam and carbapenems exhibit enhanced potencies against drug-resistant Mycobacterium abscessus. Future Microbiol. 2017, 12, 473-480. [CrossRef]

105. Lefebvre, A.L.; Le Moigne, V.; Bernut, A.; Veckerle, C.; Compain, F.; Herrmann, J.L.; Kremer, L.; Arthur, M.; Mainardi, J.L. Inhibition of the beta-Lactamase BlaMab by Avibactam Improves the In Vitro and In Vivo Efficacy of Imipenem against Mycobacterium abscessus. Antimicrob. Agents Chemother. 2017, 61, e02440-16. [CrossRef] 
106. Dubee, V.; Bernut, A.; Cortes, M.; Lesne, T.; Dorchene, D.; Lefebvre, A.L.; Hugonnet, J.E.; Gutmann, L.; Mainardi, J.L.; Herrmann, J.L.; et al. beta-Lactamase inhibition by avibactam in Mycobacterium abscessus. J. Antimicrob. Chemother. 2015, 70, 1051-1058. [CrossRef]

107. Dubee, V.; Soroka, D.; Cortes, M.; Lefebvre, A.L.; Gutmann, L.; Hugonnet, J.E.; Arthur, M.; Mainardi, J.L. Impact of beta-lactamase inhibition on the activity of ceftaroline against Mycobacterium tuberculosis and Mycobacterium abscessus. Antimicrob. Agents Chemother. 2015, 59, 2938-2941. [CrossRef]

108. Lefebvre, A.L.; Dubee, V.; Cortes, M.; Dorchene, D.; Arthur, M.; Mainardi, J.L. Bactericidal and intracellular activity of beta-lactams against Mycobacterium abscessus. J. Antimicrob. Chemother. 2016, 71, 1556-1563. [CrossRef]

109. Bentur, L.; Gur, M.; Ashkenazi, M.; Livnat-Levanon, G.; Mizrahi, M.; Tal, A.; Ghaffari, A.; Geffen, Y.; Aviram, M.; Efrati, O. Pilot study to test inhaled nitric oxide in cystic fibrosis patients with refractory Mycobacterium abscessus lung infection. J. Cyst. Fibros. 2019. [CrossRef]

110. Yaacoby-Bianu, K.; Gur, M.; Toukan, Y.; Nir, V.; Hakim, F.; Geffen, Y.; Bentur, L. Compassionate Nitric Oxide Adjuvant Treatment of Persistent Mycobacterium Infection in Cystic Fibrosis Patients. Pediatr. Infect. Dis. J. 2018, 37, 336-338. [CrossRef]

111. Chau, T.; Blade, K.; Da Silva, J.; Ghaffari, A.; Zelazny, A.; Olivier, K. High Efficacy of High-dose Nitric Oxide and its Synergistic Effect with Antibiotics against Mycobacterium Abscessus. Eur. Respirat. J. 2019, 54, OA4950. [CrossRef]

112. Dupont, C.; Viljoen, A.; Dubar, F.; Blaise, M.; Bernut, A.; Pawlik, A.; Bouchier, C.; Brosch, R.; Guerardel, Y.; Lelievre, J.; et al. A new piperidinol derivative targeting mycolic acid transport in Mycobacterium abscessus. Mol. Microbiol. 2016, 101, 515-529. [CrossRef] [PubMed]

113. Kozikowski, A.P.; Onajole, O.K.; Stec, J.; Dupont, C.; Viljoen, A.; Richard, M.; Chaira, T.; Lun, S.; Bishai, W.; Raj, V.S.; et al. Targeting Mycolic Acid Transport by Indole-2-carboxamides for the Treatment of Mycobacterium abscessus Infections. J. Med. Chem. 2017, 60, 5876-5888. [CrossRef] [PubMed]

114. Franz, N.D.; Belardinelli, J.M.; Kaminski, M.A.; Dunn, L.C.; Calado Nogueira de Moura, V.; Blaha, M.A.; Truong, D.D.; Li, W.; Jackson, M.; North, E.J. Design, synthesis and evaluation of indole-2-carboxamides with pan anti-mycobacterial activity. Bioorg. Med. Chem. 2017, 25, 3746-3755. [CrossRef] [PubMed]

115. Brown-Elliott, B.A.; Rubio, A.; Wallace, R.J., Jr. In Vitro Susceptibility Testing of a Novel Benzimidazole, SPR719, against Nontuberculous Mycobacteria. Antimicrob. Agents Chemother. 2018, 62, e01503-18. [CrossRef]

116. Locher, C.P.; Jones, S.M.; Hanzelka, B.L.; Perola, E.; Shoen, C.M.; Cynamon, M.H.; Ngwane, A.H.; Wiid, I.J.; van Helden, P.D.; Betoudji, F.; et al. A novel inhibitor of gyrase B is a potent drug candidate for treatment of tuberculosis and nontuberculosis mycobacterial infections. Antimicrob. Agents Chemother. 2015, 59, 1455-1465. [CrossRef]

117. Cynamon, M.; Jureller, J.; Desai, B.; Ramachandran, K.; Sklaney, M.; Grossman, T.H. In vitro activity of TP-271 against Mycobacterium abscessus, Mycobacterium fortuitum, and Nocardia species. Antimicrob. Agents Chemother. 2012, 56, 3986-3988. [CrossRef]

118. Madani, A.; Ridenour, J.N.; Martin, B.P.; Paudel, R.R.; Abdul Basir, A.; Le Moigne, V.; Herrmann, J.L.; Audebert, S.; Camoin, L.; Kremer, L.; et al. Cyclipostins and Cyclophostin Analogues as Multitarget Inhibitors That Impair Growth of Mycobacterium abscessus. ACS Infect. Dis. 2019, 5, 1597-1608. [CrossRef]

119. Nguyen, P.C.; Madani, A.; Santucci, P.; Martin, B.P.; Paudel, R.R.; Delattre, S.; Herrmann, J.L.; Spilling, C.D.; Kremer, L.; Canaan, S.; et al. Cyclophostin and Cyclipostins analogues, new promising molecules to treat mycobacterial-related diseases. Int. J. Antimicrob. Agents 2018, 51, 651-654. [CrossRef]

120. Baranyai, Z.; Kratky, M.; Vinsova, J.; Szabo, N.; Senoner, Z.; Horvati, K.; Stolarikova, J.; David, S.; Bosze, S. Combating highly resistant emerging pathogen Mycobacterium abscessus and Mycobacterium tuberculosis with novel salicylanilide esters and carbamates. Eur. J. Med. Chem. 2015, 101, 692-704. [CrossRef]

121. Kratky, M.; Bosze, S.; Baranyai, Z.; Szabo, I.; Stolarikova, J.; Paraskevopoulos, G.; Vinsova, J. Synthesis and in vitro biological evaluation of 2-(phenylcarbamoyl)phenyl 4-substituted benzoates. Bioorg. Med. Chem. 2015, 23, 868-875. [CrossRef] [PubMed]

122. Dubuisson, T.; Bogatcheva, E.; Krishnan, M.Y.; Collins, M.T.; Einck, L.; Nacy, C.A.; Reddy, V.M. In vitro antimicrobial activities of capuramycin analogues against non-tuberculous mycobacteria. J. Antimicrob. Chemother. 2010, 65, 2590-2597. [CrossRef] [PubMed] 
123. Liu, X.; Jin, Y.; Cai, W.; Green, K.D.; Goswami, A.; Garneau-Tsodikova, S.; Nonaka, K.; Baba, S.; Funabashi, M.; Yang, Z.; et al. A biocatalytic approach to capuramycin analogues by exploiting a substrate permissive N-transacylase CapW. Org. Biomol. Chem. 2016, 14, 3956-3962. [CrossRef] [PubMed]

124. Molina-Torres, C.A.; Ocampo-Candiani, J.; Rendon, A.; Pucci, M.J.; Vera-Cabrera, L. In vitro activity of a new isothiazoloquinolone, ACH-702, against Mycobacterium tuberculosis and other mycobacteria. Antimicrob. Agents Chemother. 2010, 54, 2188-2190. [CrossRef]

125. Moraski, G.C.; Cheng, Y.; Cho, S.; Cramer, J.W.; Godfrey, A.; Masquelin, T.; Franzblau, S.G.; Miller, M.J.; Schorey, J. Imidazo[1,2-a]Pyridine-3-Carboxamides Are Active Antimicrobial Agents against Mycobacterium avium Infection In Vivo. Antimicrob. Agents Chemother. 2016, 60, 5018-5022. [CrossRef]

126. Millar, B.C.; Moore, J.E. Antimycobacterial strategies to evade antimicrobial resistance in the nontuberculous mycobacteria. Int. J. Mycobacteriol. 2019, 8, 7-21. [CrossRef]

127. Chopra, S.; Matsuyama, K.; Hutson, C.; Madrid, P. Identification of antimicrobial activity among FDA-approved drugs for combating Mycobacterium abscessus and Mycobacterium chelonae. J. Antimicrob. Chemother. 2011, 66, 1533-1536. [CrossRef]

128. Marini, E.; Di Giulio, M.; Ginestra, G.; Magi, G.; Di Lodovico, S.; Marino, A.; Facinelli, B.; Cellini, L.; Nostro, A. Efficacy of carvacrol against resistant rapidly growing mycobacteria in the planktonic and biofilm growth mode. PLoS ONE 2019, 14, e0219038. [CrossRef]

129. Nowotarska, S.W.; Nowotarski, K.; Grant, I.R.; Elliott, C.T.; Friedman, M.; Situ, C. Mechanisms of Antimicrobial Action of Cinnamon and Oregano Oils, Cinnamaldehyde, Carvacrol, 2,5-Dihydroxybenzaldehyde, and 2-Hydroxy-5-Methoxybenzaldehyde against Mycobacterium avium subsp. paratuberculosis (Map). Foods 2017, 6, 72. [CrossRef]

130. Bax, H.I.; de Vogel, C.P.; Mouton, J.W.; de Steenwinkel, J.E.M. Omadacycline as a promising new agent for the treatment of infections with Mycobacterium abscessus. J. Antimicrob. Chemother. 2019, 74, 2930-2933. [CrossRef]

131. Minhas, R.; Sharma, S.; Kundu, S. Utilizing the Promise of Omadacycline in a Resistant, Non-tubercular Mycobacterial Pulmonary Infection. Cureus 2019, 11, e5112. [CrossRef] [PubMed]

132. Kaushik, A.; Ammerman, N.C.; Martins, O.; Parrish, N.M.; Nuermberger, E.L. In Vitro Activity of New Tetracycline Analogs Omadacycline and Eravacycline against Drug-Resistant Clinical Isolates of Mycobacterium abscessus. Antimicrob. Agents Chemother. 2019, 63. [CrossRef] [PubMed]

133. Shoen, C.; Benaroch, D.; Sklaney, M.; Cynamon, M. In Vitro Activities of Omadacycline against Rapidly Growing Mycobacteria. Antimicrob. Agents Chemother. 2019, 63. [CrossRef] [PubMed]

134. Bermudez, L.E.; Kolonoski, P.; Wu, M.; Aralar, P.A.; Inderlied, C.B.; Young, L.S. Mefloquine Is Active In Vitro and In Vivo against Mycobacterium avium Complex. Antimicrob. Agents Chemother. 1999, 43, 1870-1874. [CrossRef]

135. Bermudez, L.E.; Inderlied, C.B.; Kolonoski, P.; Chee, C.B.; Aralar, P.; Petrofsky, M.; Parman, T.; Green, C.E.; Lewin, A.H.; Ellis, W.Y.; et al. Identification of (+)-erythro-mefloquine as an active enantiomer with greater efficacy than mefloquine against Mycobacterium avium infection in mice. Antimicrob. Agents Chemother. 2012, 56, 4202-4206. [CrossRef]

136. Bermudez, L.E.; Kolonoski, P.; Petrofsky, M.; Wu, M.; Inderlied, C.B.; Young, L.S. Mefloquine, Moxifloxacin, and Ethambutol Are a Triple-Drug Alternative to Macrolide-Containing Regimens for Treatment of Mycobacterium avium Disease. J. Infect. Dis. 2003, 187, 1977-1980. [CrossRef]

137. Deshpande, D.; Srivastava, S.; Musuka, S.; Gumbo, T. Thioridazine as Chemotherapy for Mycobacterium avium Complex Diseases. Antimicrob. Agents Chemother. 2016, 60, 4652-4658. [CrossRef]

138. Srivastava, S.; Deshpande, D.; Sherman, C.M.; Gumbo, T. A 'shock and awe' thioridazine and moxifloxacin combination-based regimen for pulmonary Mycobacterium avium-intracellulare complex disease. J. Antimicrob. Chemother. 2017, 72, i43-i47. [CrossRef]

139. Boelaert, J.R.; Appelberg, R.; Gomes, M.S.; Blasi, E.; Mazzolla, R.; Grosset, J.; Lounis, N.; Soteriadou, K.; Thiakaki, M.; Taramelli, D.; et al. Experimental Results on Chloroquine and AIDS-Relataed Opportunistic Infections. J. Acquir. Immunodefic. Syndr. 2001, 300-301. [CrossRef]

140. Pavic, K.; Perkovic, I.; Pospisilova, S.; Machado, M.; Fontinha, D.; Prudencio, M.; Jampilek, J.; Coffey, A.; Endersen, L.; Rimac, H.; et al. Primaquine hybrids as promising antimycobacterial and antimalarial agents. Eur. J. Med. Chem. 2018, 143, 769-779. [CrossRef] 
141. Teixeira, C.; Vale, N.; Perez, B.; Gomes, A.; Gomes, J.R.; Gomes, P. “Recycling” classical drugs for malaria. Chem. Rev. 2014, 114, 11164-11220. [CrossRef] [PubMed]

142. Coatney, G.R. Pitfalls in a discovery: The chronicle of chloroquine. Am. J. Trop. Med. Hyg. 1963, 12, 121-128. [CrossRef] [PubMed]

143. Vale, N.; Moreira, R.; Gomes, P. Primaquine revisited six decades after its discovery. Eur. J. Med. Chem. 2009, 44, 937-953. [CrossRef] [PubMed]

144. Lougheed, K.E.; Taylor, D.L.; Osborne, S.A.; Bryans, J.S.; Buxton, R.S. New anti-tuberculosis agents amongst known drugs. Tuberculosis 2009, 89, 364-370. [CrossRef]

145. Ferraz, R.; Noronha, J.; Murtinheira, F.; Nogueira, F.; Machado, M.; Prudêncio, M.; Parapini, S.; D'Alessandro, S.; Teixeira, C.; Gomes, A.; et al. Primaquine-based ionic liquids as a novel class of antimalarial hits. RSC Adv. 2016, 6, 56134-56138. [CrossRef]

146. Ferraz, R.; Pinheiro, M.; Gomes, A.; Teixeira, C.; Prudencio, C.; Reis, S.; Gomes, P. Effects of novel triple-stage antimalarial ionic liquids on lipid membrane models. Bioorg. Med. Chem. Lett. 2017, 27, 4190-4193. [CrossRef]

147. Ferraz, R.; Teixeira, C.; Gomes, P.; Prudêncio, C. Chapter 16. Bioactivity of Ionic Liquids. In Ionic Liquid Devices; The Royal Society of Chemistry: London, UK, 2018; pp. 404-422.

148. Ferraz, R.; Teixeira, V.; Rodrigues, D.; Fernandes, R.; Prudêncio, C.; Noronha, J.P.; Petrovski, Ž.; Branco, L.C. Antibacterial activity of Ionic Liquids based on ampicillin against resistant bacteria. RSC Adv. 2014, 4, 4301-4307. [CrossRef]

149. Gomes, A.; Ferraz, R.; Ficker, L.; Collins, M.S.; Prudencio, C.; Cushion, M.T.; Teixeira, C.; Gomes, P. Chloroquine Analogues as Leads against Pneumocystis Lung Pathogens. Antimicrob. Agents Chemother. 2018, 62. [CrossRef]

150. Bento, C.M. Evaluation of the Effects of Selected Ionic Liquids against Mycobacterium avium. Master's Thesis, University of Porto, Porto, Portugal, 2019.

151. Nguyen, L.T.; Haney, E.F.; Vogel, H.J. The expanding scope of antimicrobial peptide structures and their modes of action. Trends Biotechnol. 2011, 29, 464-472. [CrossRef]

152. Hancock, R.E.; Haney, E.F.; Gill, E.E. The immunology of host defence peptides: Beyond antimicrobial activity. Nat. Rev. Immunol. 2016, 16, 321-334. [CrossRef]

153. Silva, T.; Gomes, M.S. Immuno-Stimulatory Peptides as a Potential Adjunct Therapy against Intra-Macrophagic Pathogens. Molecules 2017, 22, 1297. [CrossRef] [PubMed]

154. Sharma, R.; Saikia, U.N.; Sharma, S.; Verma, I. Activity of human beta defensin-1 and its motif against active and dormant Mycobacterium tuberculosis. Appl. Microbiol. Biotechnol. 2017, 101, 7239-7248. [CrossRef] [PubMed]

155. Gutsmann, T. Interaction between antimicrobial peptides and mycobacteria. Biochim. Biophys. Acta 2016, 1858, 1034-1043. [CrossRef] [PubMed]

156. AlMatar, M.; Makky, E.A.; Yakici, G.; Var, I.; Kayar, B.; Koksal, F. Antimicrobial peptides as an alternative to anti-tuberculosis drugs. Pharmacol. Res. 2018, 128, 288-305. [CrossRef]

157. Yuk, J.M.; Shin, D.M.; Lee, H.M.; Yang, C.S.; Jin, H.S.; Kim, K.K.; Lee, Z.W.; Lee, S.H.; Kim, J.M.; Jo, E.K. Vitamin D3 induces autophagy in human monocytes/macrophages via cathelicidin. Cell Host Microbe 2009, 6, 231-243. [CrossRef]

158. Rivas-Santiago, B.; Castaneda-Delgado, J.E.; Rivas Santiago, C.E.; Waldbrook, M.; Gonzalez-Curiel, I.; Leon-Contreras, J.C.; Enciso-Moreno, J.A.; del Villar, V.; Mendez-Ramos, J.; Hancock, R.E.; et al. Ability of innate defence regulator peptides IDR-1002, IDR-HH2 and IDR-1018 to protect against Mycobacterium tuberculosis infections in animal models. PLoS ONE 2013, 8, e59119. [CrossRef]

159. Sharma, S.; Verma, I.; Khuller, G.K. Therapeutic potential of human neutrophil peptide 1 against experimental tuberculosis. Antimicrob. Agents Chemother. 2001, 45, 639-640. [CrossRef]

160. Kalita, A.; Verma, I.; Khuller, G.K. Role of human neutrophil peptide-1 as a possible adjunct to antituberculosis chemotherapy. J. Infect. Dis. 2004, 190, 1476-1480. [CrossRef]

161. Yoshida, N.; Tani, Y.; Ogata, K. Cryomycin, a new peptide antibiotic produced only at low temperature. J. Antibiot. 1972, 25, 653-659. [CrossRef]

162. Gao, W.; Kim, J.Y.; Anderson, J.R.; Akopian, T.; Hong, S.; Jin, Y.Y.; Kandror, O.; Kim, J.W.; Lee, I.A.; Lee, S.Y.; et al. The cyclic peptide ecumicin targeting $\mathrm{ClpC} 1$ is active against Mycobacterium tuberculosis in vivo. Antimicrob. Agents Chemother. 2015, 59, 880-889. [CrossRef] 
163. Gavrish, E.; Sit, C.S.; Cao, S.; Kandror, O.; Spoering, A.; Peoples, A.; Ling, L.; Fetterman, A.; Hughes, D.; Bissell, A.; et al. Lassomycin, a ribosomally synthesized cyclic peptide, kills mycobacterium tuberculosis by targeting the ATP-dependent protease ClpC1P1P2. Chem. Biol. 2014, 21, 509-518. [CrossRef] [PubMed]

164. Carroll, J.; Draper, L.A.; O'Connor, P.M.; Coffey, A.; Hill, C.; Ross, R.P.; Cotter, P.D.; O’Mahony, J. Comparison of the activities of the lantibiotics nisin and lacticin 3147 against clinically significant mycobacteria. Int. J. Antimicrob. Agents 2010, 36, 132-136. [CrossRef] [PubMed]

165. Carroll, J.; Field, D.; O'Connor, P.M.; Cotter, P.D.; Coffey, A.; Hill, C.; Ross, R.P.; O'Mahony, J. Gene encoded antimicrobial peptides, a template for the design of novel anti-mycobacterial drugs. Bioeng. Bugs 2010, 1 , 408-412. [CrossRef] [PubMed]

166. Ali, Z.I.; Saudi, A.M.; Albrecht, R.; Talaat, A.M. The inhibitory effect of nisin on Mycobacterium avium ssp. paratuberculosis and its effect on mycobacterial cell wall. J. Dairy Sci. 2019, 102, 4935-4944. [CrossRef]

167. Cirone, K.M.; Lahiri, P.; Holani, R.; Tan, Y.L.; Arrazuria, R.; De Buck, J.; Barkema, H.W.; Cobo, E.R. Synthetic cathelicidin LL-37 reduces Mycobacterium avium subsp. paratuberculosis internalization and pro-inflammatory cytokines in macrophages. Cell Tissue Res. 2019. [CrossRef]

168. Mohanty, S.; Jena, P.; Mehta, R.; Pati, R.; Banerjee, B.; Patil, S.; Sonawane, A. Cationic antimicrobial peptides and biogenic silver nanoparticles kill mycobacteria without eliciting DNA damage and cytotoxicity in mouse macrophages. Antimicrob. Agents Chemother. 2013, 57, 3688-3698. [CrossRef] [PubMed]

169. Ogata, K.; Linzer, B.A.; Zuberi, R.I.; Ganz, T.; Lehrer, R.I.; Catanzaro, A. Activity of defensins from human neutrophilic granulocytes against Mycobacterium avium-Mycobacterium intracellulare. Infect. Immun. 1992, 60, 4720-4725. [CrossRef]

170. Silva, T.; Magalhaes, B.; Maia, S.; Gomes, P.; Nazmi, K.; Bolscher, J.G.; Rodrigues, P.N.; Bastos, M.; Gomes, M.S. Killing of Mycobacterium avium by lactoferricin peptides: Improved activity of arginine- and D-amino-acid-containing molecules. Antimicrob. Agents Chemother. 2014, 58, 3461-3467. [CrossRef]

171. Silva, T.; Moreira, A.C.; Nazmi, K.; Moniz, T.; Vale, N.; Rangel, M.; Gomes, P.; Bolscher, J.G.M.; Rodrigues, P.N.; Bastos, M.; et al. Lactoferricin Peptides Increase Macrophages' Capacity To Kill Mycobacterium avium. mSphere 2017, 2, e00301-17. [CrossRef]

172. Adhya, M.; Jeung, H.D.; Kang, H.S.; Choi, K.S.; Lee, D.S.; Cho, M. Cloning and localization of MCdef, a defensin from Manila clams (Ruditapes philippinarum). Comp. Biochem. Physiol. B Biochem. Mol. Biol. 2012, 161, 25-31. [CrossRef]

173. Trentini, M.M.; das Neves, R.C.; Santos, B.P.; DaSilva, R.A.; de Souza, A.C.; Mortari, M.R.; Schwartz, E.F.; Kipnis, A.; Junqueira-Kipnis, A.P. Non-disulfide-Bridge Peptide 5.5 from the Scorpion Hadrurus gertschi Inhibits the Growth of Mycobacterium abscessus subsp. massiliense. Front. Microbiol. 2017, 8, 273. [CrossRef] [PubMed]

174. das Neves, R.C.; Trentini, M.M.; de Castro e Silva, J.; Simon, K.S.; Bocca, A.L.; Silva, L.P.; Mortari, M.R.; Kipnis, A.; Junqueira-Kipnis, A.P. Antimycobacterial Activity of a New Peptide Polydim-I Isolated from Neotropical Social Wasp Polybia dimorpha. PLoS ONE 2016, 11, e0149729. [CrossRef] [PubMed]

175. Marques-Neto, L.M.; Trentini, M.M.; das Neves, R.C.; Resende, D.P.; Procopio, V.O.; da Costa, A.C.; Kipnis, A.; Mortari, M.R.; Schwartz, E.F.; Junqueira-Kipnis, A.P. Antimicrobial and Chemotactic Activity of Scorpion-Derived Peptide, ToAP2, against Mycobacterium massiliensis. Toxins 2018, 10, 219. [CrossRef] [PubMed]

176. Silva, J.C.; Neto, L.M.; Neves, R.C.; Goncalves, J.C.; Trentini, M.M.; Mucury-Filho, R.; Smidt, K.S.; Fensterseifer, I.C.; Silva, O.N.; Lima, L.D.; et al. Evaluation of the antimicrobial activity of the mastoparan Polybia-MPII isolated from venom of the social wasp Pseudopolybia vespiceps testacea (Vespidae, Hymenoptera). Int. J. Antimicrob. Agents 2017, 49, 167-175. [CrossRef]

177. D’Herelle, F. Sur un microbe invisible antagoniste des bacilles dysentériques. C. R. Acad. Sci. 1917, 165, 373-375.

178. Azimi, T.; Mosadegh, M.; Nasiri, M.J.; Sabour, S.; Karimaei, S.; Nasser, A. Phage therapy as a renewed therapeutic approach to mycobacterial infections: A comprehensive review. Infect. Drug Resist. 2019, 12, 2943-2959. [CrossRef]

179. Dams, D.; Briers, Y. Enzybiotics: Enzyme-Based Antibacterials as Therapeutics. Adv. Exp. Med. Biol. 2019, 1148, 233-253. [CrossRef]

180. Nieth, A.; Verseux, C.; Barnert, S.; Suss, R.; Romer, W. A first step toward liposome-mediated intracellular bacteriophage therapy. Expert Opin. Drug Deliv. 2015, 12, 1411-1424. [CrossRef] 
181. Li, Q.; Zhou, M.; Fan, X.; Yan, J.; Li, W.; Xie, J. Mycobacteriophage SWU1 gp39 can potentiate multiple antibiotics against Mycobacterium via altering the cell wall permeability. Sci. Rep. 2016, 6, 28701. [CrossRef]

182. Broxmeyer, L.; Sosnowska, D.; Miltner, E.; Chacon, O.; Wagner, D.; McGarvey, J.; Barletta, R.G.; Bermudez, L.E. Killing of Mycobacterium avium and Mycobacterium tuberculosis by a mycobacteriophage delivered by a nonvirulent mycobacterium: A model for phage therapy of intracellular bacterial pathogens. J. Infect. Dis. 2002, 186, 1155-1160. [CrossRef]

183. Danelishvili, L.; Young, L.S.; Bermudez, L.E. In vivo efficacy of phage therapy for Mycobacterium avium infection as delivered by a nonvirulent mycobacterium. Microb. Drug Resist. 2006, 12, 1-6. [CrossRef] [PubMed]

184. Payne, K.; Sun, Q.; Sacchettini, J.; Hatfull, G.F. Mycobacteriophage Lysin B is a novel mycolylarabinogalactan esterase. Mol. Microbiol. 2009, 73, 367-381. [CrossRef] [PubMed]

185. Catalao, M.J.; Milho, C.; Gil, F.; Moniz-Pereira, J.; Pimentel, M. A second endolysin gene is fully embedded in-frame with the lysA gene of mycobacteriophage Ms6. PLoS ONE 2011, 6, e20515. [CrossRef] [PubMed]

186. Grover, N.; Paskaleva, E.E.; Mehta, K.K.; Dordick, J.S.; Kane, R.S. Growth inhibition of Mycobacterium smegmatis by mycobacteriophage-derived enzymes. Enzyme Microb. Technol. 2014, 63, 1-6. [CrossRef] [PubMed]

187. Lai, M.J.; Liu, C.C.; Jiang, S.J.; Soo, P.C.; Tu, M.H.; Lee, J.J.; Chen, Y.H.; Chang, K.C. Antimycobacterial Activities of Endolysins Derived From a Mycobacteriophage, BTCU-1. Molecules 2015, 20, 19277-19290. [CrossRef]

188. Silva-Gomes, S.; Vale-Costa, S.; Appelberg, R.; Gomes, M.S. Iron in intracellular infection: To provide or to deprive? Front. Cell Infect. Microbiol. 2013, 3, 96. [CrossRef]

189. Sritharan, M. Iron Homeostasis in Mycobacterium tuberculosis: Mechanistic Insights into Siderophore-Mediated Iron Uptake. J. Bacteriol. 2016, 198, 2399-2409. [CrossRef]

190. Jones, C.M.; Niederweis, M. Mycobacterium tuberculosis can utilize heme as an iron source. J. Bacteriol. 2011, 193, 1767-1770. [CrossRef]

191. Tullius, M.V.; Harmston, C.A.; Owens, C.P.; Chim, N.; Morse, R.P.; McMath, L.M.; Iniguez, A.; Kimmey, J.M.; Sawaya, M.R.; Whitelegge, J.P.; et al. Discovery and characterization of a unique mycobacterial heme acquisition system. Proc. Natl. Acad. Sci. USA 2011, 108, 5051-5056. [CrossRef] [PubMed]

192. Nambu, S.; Matsui, T.; Goulding, C.W.; Takahashi, S.; Ikeda-Saito, M. A new way to degrade heme: The Mycobacterium tuberculosis enzyme MhuD catalyzes heme degradation without generating CO. J. Biol. Chem. 2013, 288, 10101-10109. [CrossRef]

193. Kelley, V.A.; Schorey, J.S. Mycobacterium's arrest of phagosome maturation in macrophages requires Rab5 activity and accessibility to iron. Mol. Biol. Cell 2003, 14, 3366-3377. [CrossRef] [PubMed]

194. Ojha, A.; Hatfull, G.F. The role of iron in Mycobacterium smegmatis biofilm formation: The exochelin siderophore is essential in limiting iron conditions for biofilm formation but not for planktonic growth. Mol. Microbiol. 2007, 66, 468-483. [CrossRef] [PubMed]

195. Yang, Y.; Thomas, J.; Li, Y.; Vilcheze, C.; Derbyshire, K.M.; Jacobs, W.R., Jr.; Ojha, A.K. Defining a temporal order of genetic requirements for development of mycobacterial biofilms. Mol. Microbiol. 2017, 105, 794-809. [CrossRef] [PubMed]

196. De Voss, J.J.; Rutter, K.; Schroeder, B.G.; Su, H.; Zhu, Y.; Barry, C.E., 3rd. The salicylate-derived mycobactin siderophores of Mycobacterium tuberculosis are essential for growth in macrophages. Proc. Natl. Acad. Sci. USA 2000, 97, 1252-1257. [CrossRef] [PubMed]

197. Reddy, P.V.; Puri, R.V.; Chauhan, P.; Kar, R.; Rohilla, A.; Khera, A.; Tyagi, A.K. Disruption of mycobactin biosynthesis leads to attenuation of Mycobacterium tuberculosis for growth and virulence. J. Infect. Dis. 2013, 208, 1255-1265. [CrossRef] [PubMed]

198. Gomes, A.C.; Moreira, A.C.; Mesquita, G.; Gomes, M.S. Modulation of Iron Metabolism in Response to Infection: Twists for All Tastes. Pharmaceuticals 2018, 11, 84. [CrossRef]

199. Gomes, M.S.; Dom, G.; Pedrosa, J.; Boelaert, J.R.; Appelberg, R. Effects of iron deprivation on Mycobacterium avium growth. Tuber Lung Dis. 1999, 79, 321-328. [CrossRef]

200. Fernandes, S.S.; Nunes, A.; Gomes, A.R.; de Castro, B.; Hider, R.C.; Rangel, M.; Appelberg, R.; Gomes, M.S. Identification of a new hexadentate iron chelator capable of restricting the intramacrophagic growth of Mycobacterium avium. Microbes Infect. 2010, 12, 287-294. [CrossRef] 
201. Moniz, T.; Leite, A.; Silva, T.; Gameiro, P.; Gomes, M.S.; de Castro, B.; Rangel, M. The influence of functional groups on the permeation and distribution of antimycobacterial rhodamine chelators. J. Inorg. Biochem. 2017, 175, 138-147. [CrossRef]

202. Moniz, T.; Nunes, A.; Silva, A.M.; Queiros, C.; Ivanova, G.; Gomes, M.S.; Rangel, M. Rhodamine labeling of 3-hydroxy-4-pyridinone iron chelators is an important contribution to target Mycobacterium avium infection. J. Inorg. Biochem. 2013, 121, 156-166. [CrossRef]

203. Moniz, T.; Silva, D.; Silva, T.; Gomes, M.S.; Rangel, M. Antimycobacterial activity of rhodamine 3,4-HPO iron chelators against Mycobacterium avium: Analysis of the contribution of functional groups and of chelator's combination with ethambutol. MedChem Comm 2015, 6, 2194-2203. [CrossRef]

204. Tatano, Y.; Kanehiro, Y.; Sano, C.; Shimizu, T.; Tomioka, H. ATP exhibits antimicrobial action by inhibiting bacterial utilization of ferric ions. Sci. Rep. 2015, 5, 8610. [CrossRef] [PubMed]

205. Dragset, M.S.; Poce, G.; Alfonso, S.; Padilla-Benavides, T.; Ioerger, T.R.; Kaneko, T.; Sacchettini, J.C.; Biava, M.; Parish, T.; Arguello, J.M.; et al. A novel antimycobacterial compound acts as an intracellular iron chelator. Antimicrob. Agents Chemother. 2015, 59, 2256-2264. [CrossRef] [PubMed]

206. Kaufmann, S.H.E.; Dorhoi, A.; Hotchkiss, R.S.; Bartenschlager, R. Host-directed therapies for bacterial and viral infections. Nat. Rev. Drug Discov. 2018, 17, 35-56. [CrossRef] [PubMed]

207. Torfs, E.; Piller, T.; Cos, P.; Cappoen, D. Opportunities for Overcoming Mycobacterium tuberculosis Drug Resistance: Emerging Mycobacterial Targets and Host-Directed Therapy. Int. J. Mol. Sci. 2019, 20, 2868. [CrossRef]

208. Silva, R.A.; Pais, T.F.; Appelberg, R. Evaluation of IL-12 in Immunotherapy and Vaccine Design in Experimental Mycobacterium avium Infections. J. Immunol. 1998, 5578-5585.

209. Kim, S.H.; Cho, D.; Kim, T.S. Induction of in vivo resistance to Mycobacterium avium infection by intramuscular injection with DNA encoding interleukin-18. Immunology 2001, 234-241. [CrossRef]

210. Skerry, C.; Harper, J.; Klunk, M.; Bishai, W.R.; Jain, S.K. Adjunctive TNF inhibition with standard treatment enhances bacterial clearance in a murine model of necrotic TB granulomas. PLoS ONE 2012, 7, e39680. [CrossRef]

211. Winthrop, K.L.; Chang, E.; Yamashita, S.; Iademarco, M.F.; LoBue, P.A. Nontuberculous mycobacteria infections and anti-tumor necrosis factor-alpha therapy. Emerg. Infect. Dis. 2009, 15, 1556-1561. [CrossRef]

212. Yoo, J.W.; Jo, K.W.; Kang, B.H.; Kim, M.Y.; Yoo, B.; Lee, C.K.; Kim, Y.G.; Yang, S.K.; Byeon, J.S.; Kim, K.J.; et al. Mycobacterial diseases developed during anti-tumour necrosis factor-alpha therapy. Eur. Respir. J. 2014, 44, 1289-1295. [CrossRef]

213. Dorhoi, A.; Kaufmann, S.H. Tumor necrosis factor alpha in mycobacterial infection. Semin. Immunol. 2014, 26, 203-209. [CrossRef] [PubMed]

214. Chakravarty, S.D.; Zhu, G.; Tsai, M.C.; Mohan, V.P.; Marino, S.; Kirschner, D.E.; Huang, L.; Flynn, J.; Chan, J. Tumor necrosis factor blockade in chronic murine tuberculosis enhances granulomatous inflammation and disorganizes granulomas in the lungs. Infect. Immun. 2008, 76, 916-926. [CrossRef] [PubMed]

215. Shu, C.C.; Wang, J.Y.; Wu, M.F.; Wu, C.T.; Lai, H.C.; Lee, L.N.; Chiang, B.L.; Yu, C.J. Attenuation of lymphocyte immune responses during Mycobacterium avium complex-induced lung disease due to increasing expression of programmed death-1 on lymphocytes. Sci. Rep. 2017, 7, 42004. [CrossRef] [PubMed]

216. Okazaki, T.; Chikuma, S.; Iwai, Y.; Fagarasan, S.; Honjo, T. A rheostat for immune responses: The unique properties of PD-1 and their advantages for clinical application. Nat. Immunol. 2013, 14, 1212-1218. [CrossRef]

217. Zullo, A.J.; Jurcic Smith, K.L.; Lee, S. Mammalian target of Rapamycin inhibition and mycobacterial survival are uncoupled in murine macrophages. BMC Biochem. 2014, 15, 4. [CrossRef]

218. Mizushima, N. Autophagy: Process and function. Genes Dev. 2007, 21, 2861-2873. [CrossRef]

219. Zullo, A.J.; Lee, S. Mycobacterial induction of autophagy varies by species and occurs independently of mammalian target of rapamycin inhibition. J. Biol. Chem. 2012, 287, 12668-12678. [CrossRef]

(C) 2020 by the authors. Licensee MDPI, Basel, Switzerland. This article is an open access article distributed under the terms and conditions of the Creative Commons Attribution (CC BY) license (http://creativecommons.org/licenses/by/4.0/). 